\title{
The use of medicinal plants by the population from the Protected Landscape of "Serra de Montejunto", Portugal
}

\author{
Cidália Vinagre', Sandra Vinagre $2^{2^{*}}$ and Ermelinda Carrilho ${ }^{1}$
}

\begin{abstract}
Background: Traditional medicine has an important role in local communities, who use plants in the treatment of various diseases. The research of traditional uses of medicinal plants allows us to document and analyze ethnopharmacological practices. This paper reports on an ethnobotanical survey that was conducted in the Protected Landscape of the "Serra de Montejunto", a Portuguese area in the west of the Iberian Peninsula, where these studies were nonexistent.

Methods: The information was obtained through semi-structured ethnobotanical interviews with 78 informants, who were selected from several zones from the study area to have a representative of the entire landscape, during 2014. Local medicinal uses of plants were identified and grouped into 10 categories through data analysis, in quantitative indices such as the relative frequency citation (RFC), the cultural importance index (CI), and the informant consensus factor $\left(F_{I C}\right)$. These were used to evaluate the importance of medicinal plants to the locals.
\end{abstract}

Results: In the fieldwork, we found 105 taxa used as medicinal plants which belong to 46 families, where Rosaceae, Asteraceae, Fabaceae, and Lamiaceae are the ones with more diversity. The plants were grouped into 10 categories, where the digestive category is the most cited, with 54 taxa, and the ophthalmological category is the less cited, with only one taxon. Leaves and aerial parts are the components most used. Infusion is the most reported form of preparation, along with the oral administration. Most plants referred in this study are still in use today; only 17 are no longer used at the present time because habits have changed. A catalog of medicinal plants was also drawn up.

Conclusion: This work enabled us to explore once more our experiences and memories as well as the ancestral use of plants with the goal of expanding ethnopharmacological knowledge. The absence of ethnobotanical studies in this region led us to gather information about useful plants and their applications and benefits. This research helps in the conservation effort of the collective knowledge of medicinal plants for future generations. However, a detailed analysis by body system is still required.

Keywords: Ethnobotany, Medicinal plants, Ethnopharmacology, Protected Landscape of "Serra de Montejunto", Portugal

\section{Background}

Plants have been used since ancient times by humans. Several purposes have been served by them such as food, spices, medicine, ritual components. The knowledge of plants and their benefits have been accumulated and passed on through the generations, through writing or

\footnotetext{
*Correspondence: smv@uevora.pt

${ }^{2}$ Departamento de Matemática, CIMA, ECT, Universidade de Évora, Rua

Romão Ramalho, 59, 7000-671 Évora, Portugal

Full list of author information is available at the end of the article
}

memory. While some knowledge has been lost other has endured to present days and is still in use.

The scientific discipline dedicated to the relationship between man and the use of plants is called ethnobotany [1]. The American botanist John W. Harshberger coined the term "ethnobotany" in 1985 to describe studies of "plants used by primitive and aboriginal people" and in his 1896 publication, The purposes of ethno-botany, [2], he suggested "ethnobotany" be a field which elucidates the "cultural position of the tribes who used the plants for food, shelter or clothing," generally accepted as a

(c) The Author(s). 2019 Open Access This article is distributed under the terms of the Creative Commons Attribution 4.0 International License (http://creativecommons.org/licenses/by/4.0/), which permits unrestricted use, distribution, and 
starting point for this field as an academic discipline [3]. Therefore, ethnobotany deals directly with the interrelationship between people and plants, including all forms of perception and appropriation of plant resources [4].

The human being has always tried to find in the plants that nature so lavishly offers sustenance as well as healing for various diseases that afflicted the course of its existence [5].

Plants have always been the primary source of treatment humanity used for disease and injury. Initially, they were used empirically, selected and tested. The knowledge of their effects and toxicity was then passed on. Through this process and collective memory, many plants are still used in the traditional way. The use of plants in therapy remains, worldwide, an important means of combating diseases. Medicinal herbal products in developing countries account for $80 \%$ of drugs used [6]. The same authors state that since 2002 the World Health Organization has launched its first global strategy on traditional medicine.

Several studies on the use and effects of medicinal plants have been conducted throughout the world with a marked increase in the Iberian Peninsula. In Portugal research on ethnobotanical projects was initiated by the Portuguese Institute for Nature Conservation and Forestry. The 2000's study commissioned was titled: "Aromatic and/or Medicinal Plants in the National Network of Protected Areas". In that study, the Protected Landscape of "Serra de Montejunto" was not featured. This article however focuses solely on that region.

While Portugal is a Mediterranean region due to its edaphoclimatic conditions, the country has a high phytodiversity and inherent resources with a high potential for medical purposes [6]. For some authors, the plants from the Mediterranean region have real medicinal potential [7]. With this work, we intended to verify that in the region studied, there is a great biodiversity and a documented use of medicinal plants.

\section{Methods}

\section{Study area}

The Portuguese Protected Area of "Serra de Montejunto" was created in 1999 [8] due to the national importance of its natural vegetation. It is located in the western part of the Iberian Peninsula (Portugal), comprised of 4897.39 ha and stretches over $15 \mathrm{~km}$ with a northeast (NE)-southwest (SW) orientation; is limited by the Cadaval municipality (East) and the Alenquer municipality (West); and is in the Lisbon District (Fig. 1). It is part of the Dividing Portuguese Sector integrated into the inner Mediterranean Region $[9,10]$, and in a biogeographic context, it is a Mediterranean bioclimate, with a mesomediterranean thermotype and subhumid to humid ombrotype, according to the Rivas-Martinez Worldwide Bioclimatic Classification [11] and the Monteiro-Henriques maps [12].
This territory contains important biophysical characteristics resulting from its unique geography, in that the studied area, a large anticline of calcareous origin whose summit reaches an altitude of $666 \mathrm{~m}$ enjoys a privileged geographic location, between the coast and the Tagus Valley, encompassing the Montejunto and the Estrela mountainous, acting as a barrier to the oceanic influence, separating the rainiest part of the country from the driest. The Protected Landscape of the Montejunto Mountain, marked by millennia of anthropic action, still holds some vestiges of the primeval vegetation, which testify to the potential of the region's plant life within the scope of the Arisaro Simorrhini-Quercetum Broteroi oak forest. Concerned to the flora of Mediterranean influence, more than 750 taxa have been identified, divided by 91 botanical families, of which the Asteraceae, Fabaceae, Poaceae, and Lamiaceae families have more than a third of the floristic variety [13].

This is the specific area this work was conducted in and refers to as it explores the use of medicinal plants by the locals.

\section{Data collection}

The fieldwork was carried out in 2014, between March and December. Working with 78 informants, we obtained data about 105 medicinal taxa, belonging to 46 botanical families and a corresponding total of 2808 usereports. The information obtained in the interviews was about wild or cultivated plants, which were obtained by the interviewees themselves or by their family, and purchased plants were never considered. Local medicinal uses were identified and grouped into 10 categories: circulatory, dermatological, digestive, neurological, ophthalmological, reproductive, respiratory, skeleton and muscles, urinary, and other uses.

In gathering the data for the project, we used semistructured ethnobotanical interviews $[1,14]$ that, while informal, were acquiesced by the participants through oral agreement. The people interviewed, in their local language (Portuguese language), were either current or former residents of the area, selected because of their knowledge on the subject. Most were recommended by other locals when the topic came into question.

To complement the interviews and aid in the identification of the plants, the informants were presented with photograph portfolios and a herbarium created by the authors or invited to a field walk. Some were interviewed a second time in order to expand on the already compiled information.

This knowledge of ethnopharmacological plant uses was transmitted through oral traditions (parents or other relatives). Many of informants referred that this knowledge was also been complemented by personal experience (45) and the youngest informants reported other 

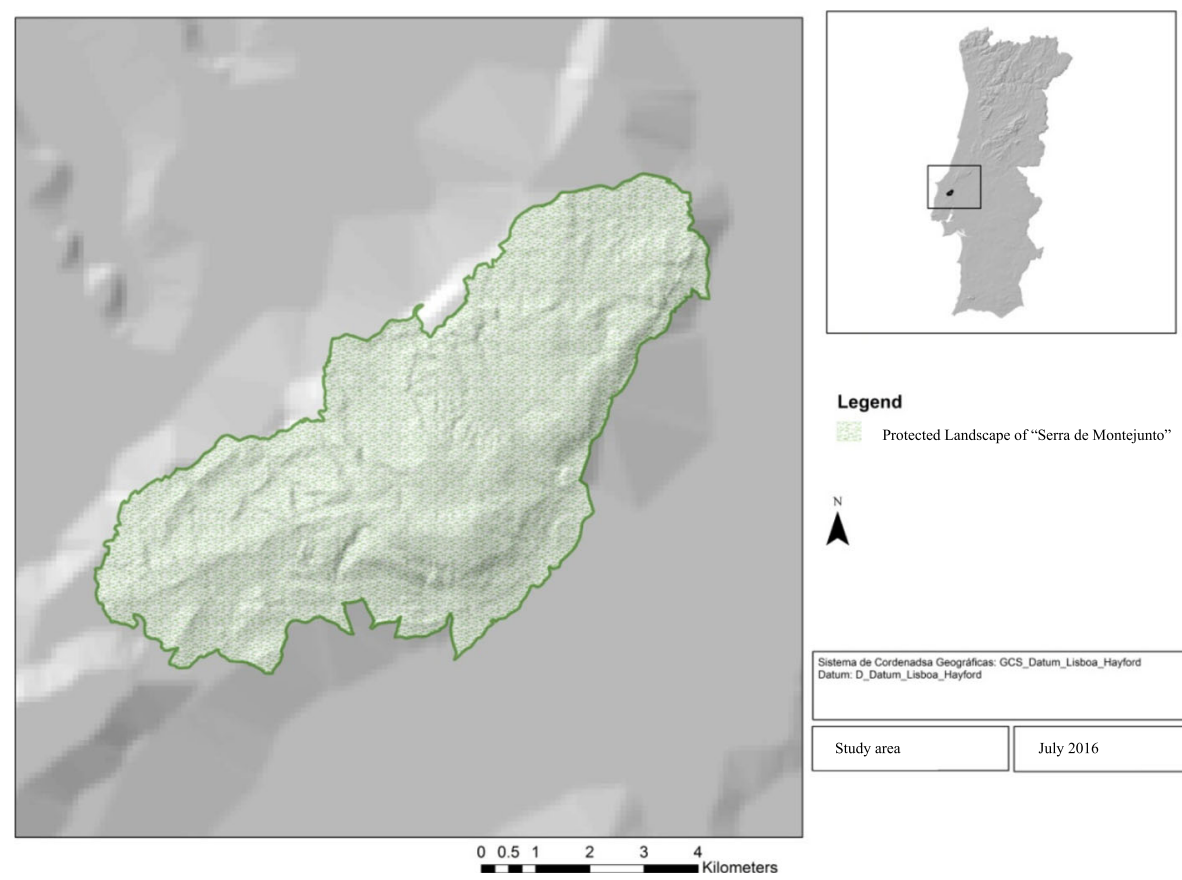

Fig. 1 Location of the study area in Portugal

sources, such as books (22), television, radio, or internet (20).

Of the total 78 interviewees, 55 were women. That represents $70 \%$ of the sample. The age of the sample varied from 19 to 94 years, averaging at 68 years old. Around $50 \%$ of this group was already retired. While four had higher education, the majority was not scientific literate, either not having gone to school or not having more than primary education (Table 1).

\section{Botanical identification}

All medicinal plants reported were identified using the following literature: Coutinho [15], Franco [16, 17], Franco and Rocha-Afonso [18-20], and Castroviejo et al. [21-36]. To compare the existing Portuguese local names, we used Rocha [37], Fernandes and Carvalho [38], and Arias [39], and the scientific names of plant species were confirmed in accordance with the International Index of Plant Name (http://www.ipni.org) and the Plant List database (http:// www.theplantlist.org).

Voucher specimens were prepared and deposited in the Herbarium "João de Carvalho e Vasconcelos" of the "Instituto Superior de Agronomia" (LISI), University of Lisbon.

Most of these medicinal plants are part of the floristic inventory of the Protected Landscape of "Serra de Montejunto" [13].

\section{Ethnobotanical data analysis}

This study was conducted in order to obtain data about the medicinal plants used in the region, their local
Portuguese names, their medicinal uses and applications, preparation, administration, condition (fresh or dried), if it is actually used (yes or no), and parts of the plant used.

The information obtained during the interviews, recorded in Table 2, was statistically analyzed. The reported plants were grouped into 10 categories, based on the body systems, each of which is divided into several subcategories, in accordance with the information gathered from the informants.

To establish a deeper pharmacological knowledge of this region, the data was also assessed using quantitative analysis, namely ethnobotanical richness $(R)$, relative frequency

Table 1 Demographic details of 78 informants

\begin{tabular}{lll}
\hline Category & Subcategory & Frequency \\
\hline Gender & Male & $23(30 \%)$ \\
& Female & $55(70 \%)$ \\
Age & 50 or less & $12(15.4 \%)$ \\
& $51-60$ & $8(10.2 \%)$ \\
& $61-70$ & $24(30.8 \%)$ \\
& $71-80$ & $21(26.9 \%)$ \\
Education level & 81 or more & $13(16.7 \%)$ \\
& Illiterate & $21(26.9 \%)$ \\
& Primary & $29(37.2 \%)$ \\
& Middle & $15(19.2 \%)$ \\
& Secondary & $9(11.6 \%)$ \\
& University & $4(5.1 \%)$ \\
\hline
\end{tabular}


citation (RFC), cultural importance index (CI), and informant consensus factor $\left(F_{\mathrm{IC}}\right)$.

The quantitative data obtained allowed for solid comparisons with other similar studies.

\section{Ethnobotanical richness}

The ethnobotanical richness $(R)$ is the number of useful medicinal species [40]. The result obtained will be compared with that of other equivalent studies carried out in Portugal [41-43].

\section{Relative frequency citation}

The relative frequency citation (RFC) is given by $\mathrm{RFC}=\mathrm{FC} /$ $N$, where FC is the total number of informants that referred to the taxon and $N$ is the total number of informants. This index reveals the importance of each species [44].

\section{Cultural importance index}

The cultural index $(\mathrm{CI})$ is given by $\mathrm{CI}=\mathrm{UR} / N$, where UR (use-reports) is the use recorded for every taxa and $N$ is the total number of informants. This index was used to estimate the cultural significance of each species, in other words, to verify, in quantitative terms, to what extent each species is present in the local culture and in the memory of the inhabitants in the study [45].

\section{Informant consensus factor}

The informant consensus factor $\left(F_{\mathrm{IC}}\right)$, testing homogeneity on the informant's knowledge, is given by the ratio between the number of use-reports $\left(n_{\mathrm{ur}}\right)$ minus the number of taxa used $\left(n_{\mathrm{t}}\right)$ and the number of use-reports minus one, that is, $F_{\mathrm{IC}}=\left(n_{\mathrm{ur}}-n_{\mathrm{t}}\right) /\left(n_{\mathrm{ur}}-1\right)$. A high value in this index (near to 1) indicates that there exist welldefined selection criteria for the species regarding a specific illness category on behalf of the informants and/or that they are in full agreement in using that species for a specific use, while a low index (near to 0 ) indicates the choice of the species was random and that there is no consensus among the informants on the medicinal use of the species [46]. The result will be compared with others known to Portugal $[41,43]$.

\section{Results and discussion}

\section{Diversity of medicinal plants and plant parts used}

In Table 2, we list the plants cited by a minimum of three different informants using the criteria of Le Grand and Wondergem and Johns et al., cited in Bonet et al., [47], organized in alphabetical order by the corresponding botanical families (46). This table also contains other data such as categories and subcategories used, as well as methods of preparation and administration and voucher numbers.

The 10 botanical families with more taxa were Rosaceae (12 species), followed by Asteraceae, Fabaceae and Lamiaceae (eight species each), Solanaceae (seven),
Apiaceae and Poaceae (four species each), Brassicaceae, and Cucurbitaceae and Malvaceae (three species each). The remaining 36 botanical families were represented by only one or two species. The most represented families coincide with those of other ethnobotanical studies in the Mediterranean area with this same methodology [41-43, 47-54].

These families predominate in local folk medicine, probably because they are widely represented in the local flora [47].

The 11 botanical families with more mentions were Malvaceae (504), Lamiaceae (220), Rosaceae (163), Poaceae (161), Rutaceae (151), Asteraceae (134), Equisetaceae (128), Apiaceae (100), Amaryllidaceae (97), Oleaceae, and Solanaceae (86 each). Note that botanical families with more taxa, mentioned above, are not necessarily the most cited.

As shown in Fig. 2, the plant parts used for medicinal proposes were in decreasing order: leaves, aerial part, flower, fruit, sap, seeds, lemon skin, root, silk, fruit peduncles, bulb, latex, and onion skin. The section "other" integrated the parts that were mentioned less than $1 \%$ (also in decreasing order: tuber, orange skin, young shoots, juice, resin, olive oil, pericarp, stem, corn kernel, mesocarp, petals, and seed coat).

The leaves, with the highest percentage of use, were also the parts most cited in other similar ethnobotanical works [42, 43, 47-49, 52, 54]. According to Bonet et al. [47], the easy accessibility of the leaves is the reason why they were used most of the times for medicinal purposes.

In most cases, the plant parts were used singularly and sometimes as a combination of two or more parts. For example, the aerial part and flower of Chamaemelum nobile (L.) All. were both used for diuretic purposes, or the aerial part, flower, and leaves of Borago officinalis L. were used to lower fevers.

Preparation and administration mode of medicinal plants The preparation of medicinal plants is done in several ways, such as alcohol maceration, cooking, direct application, direct ingestion, infusion, ointment, poultice, smoke, syrup, and vapors. The most commonly used preparations were infusions (70\% approximately), direct applications (10\% approximately), and vapors (with $7 \%$ approximately). The remaining applications have about $13 \%$ of predominance (see Fig. 3). The prime method of preparation was the infusion, which corroborates Bonet et al. [47].

It is also important to point out that in most cases, it is very difficult to separate the procedures of decoction and infusion [47], whereby we considered, in this paper, the second method, which is the main method of preparation for oral and external administration.

Also, we can see that water is the vehicle for almost all oral and external preparations and it was used in the 


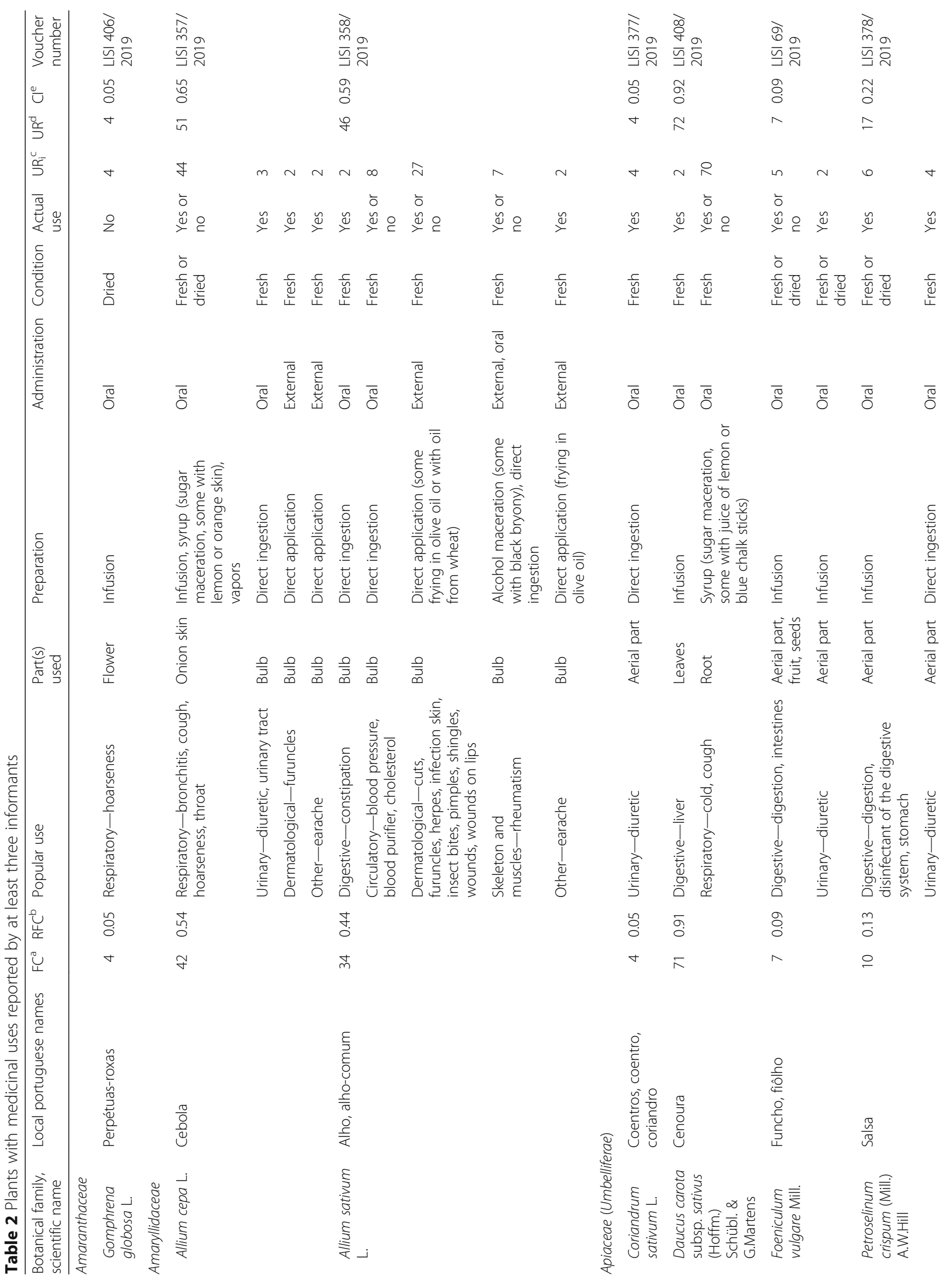




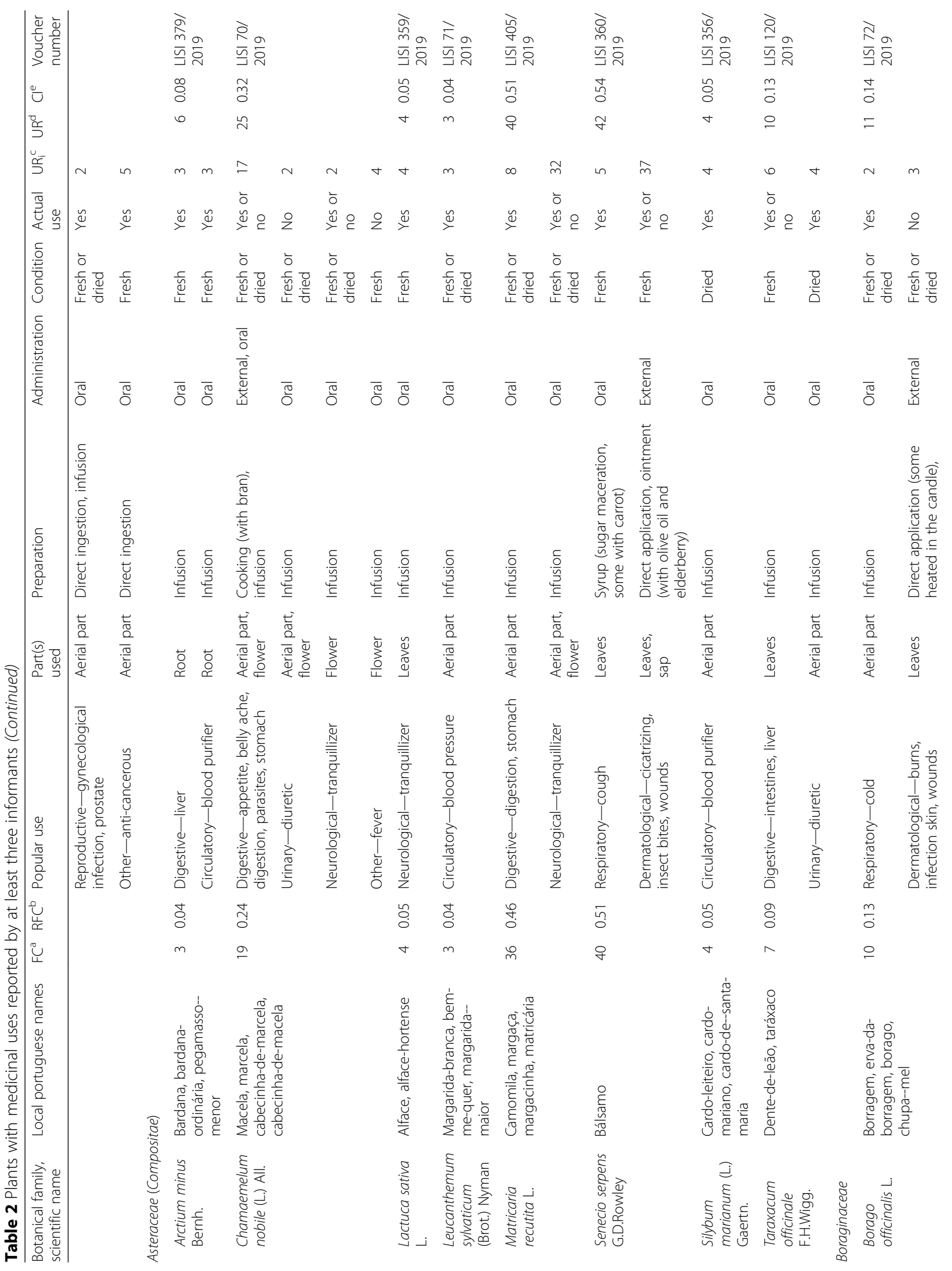




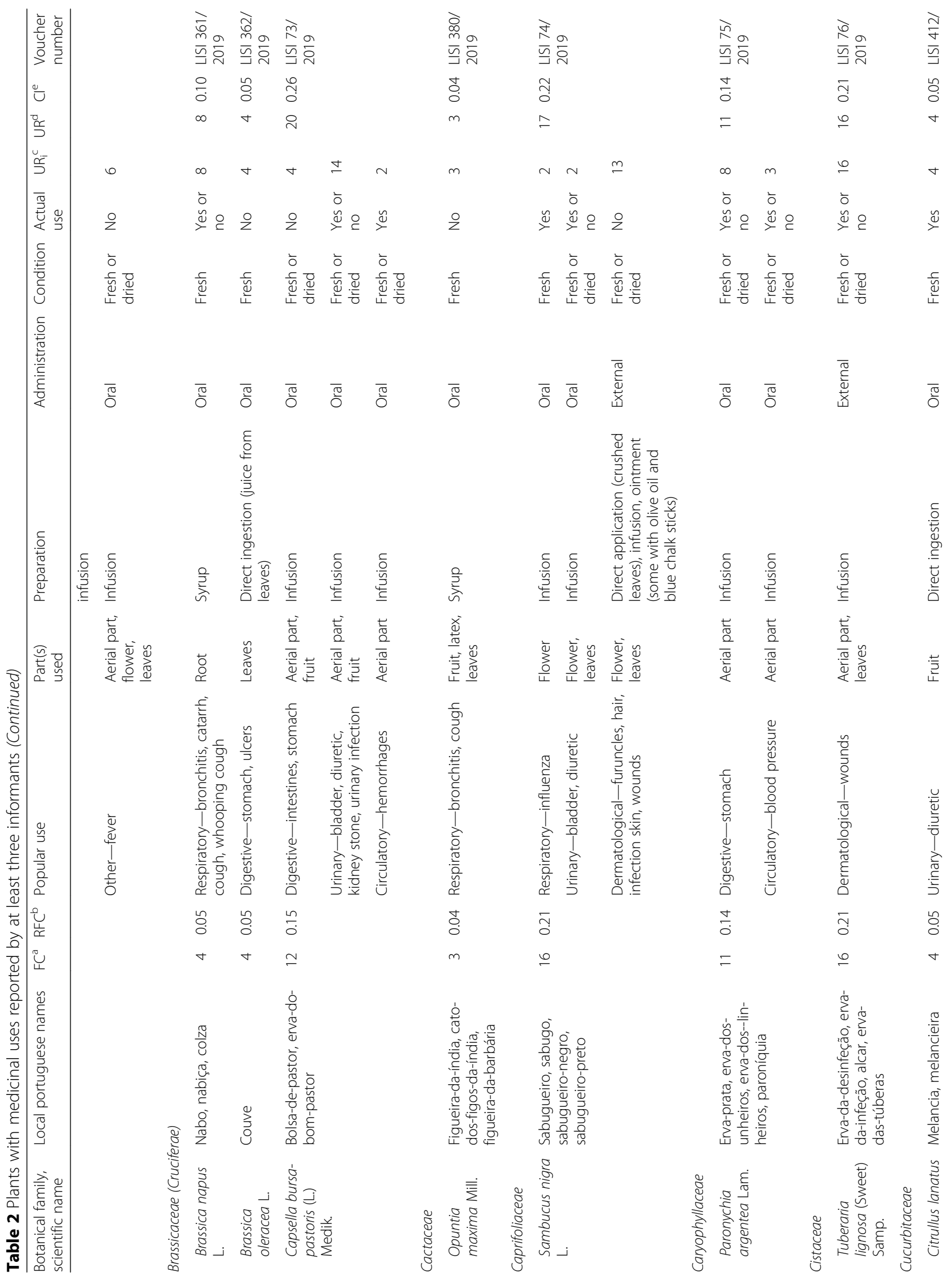




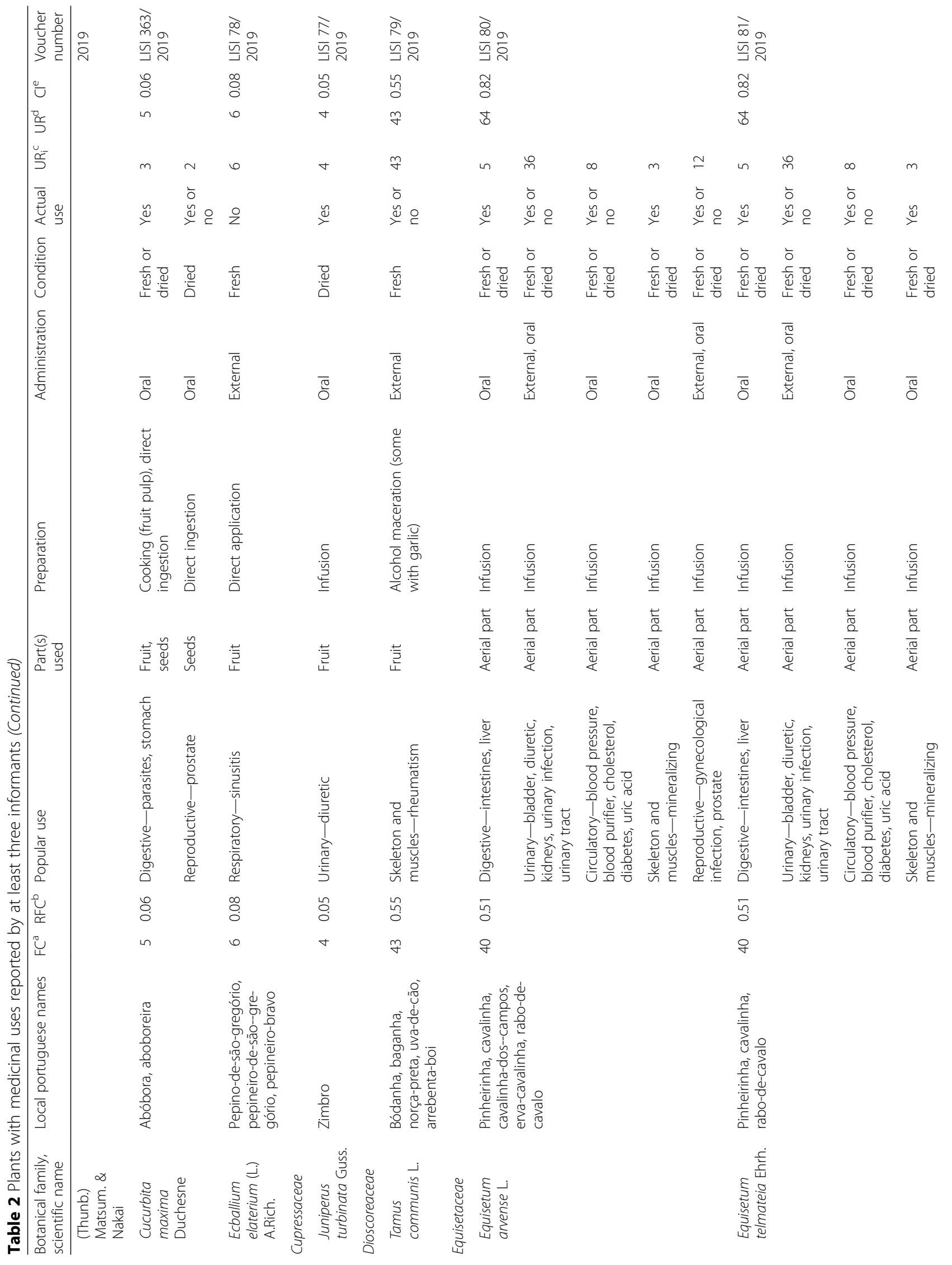




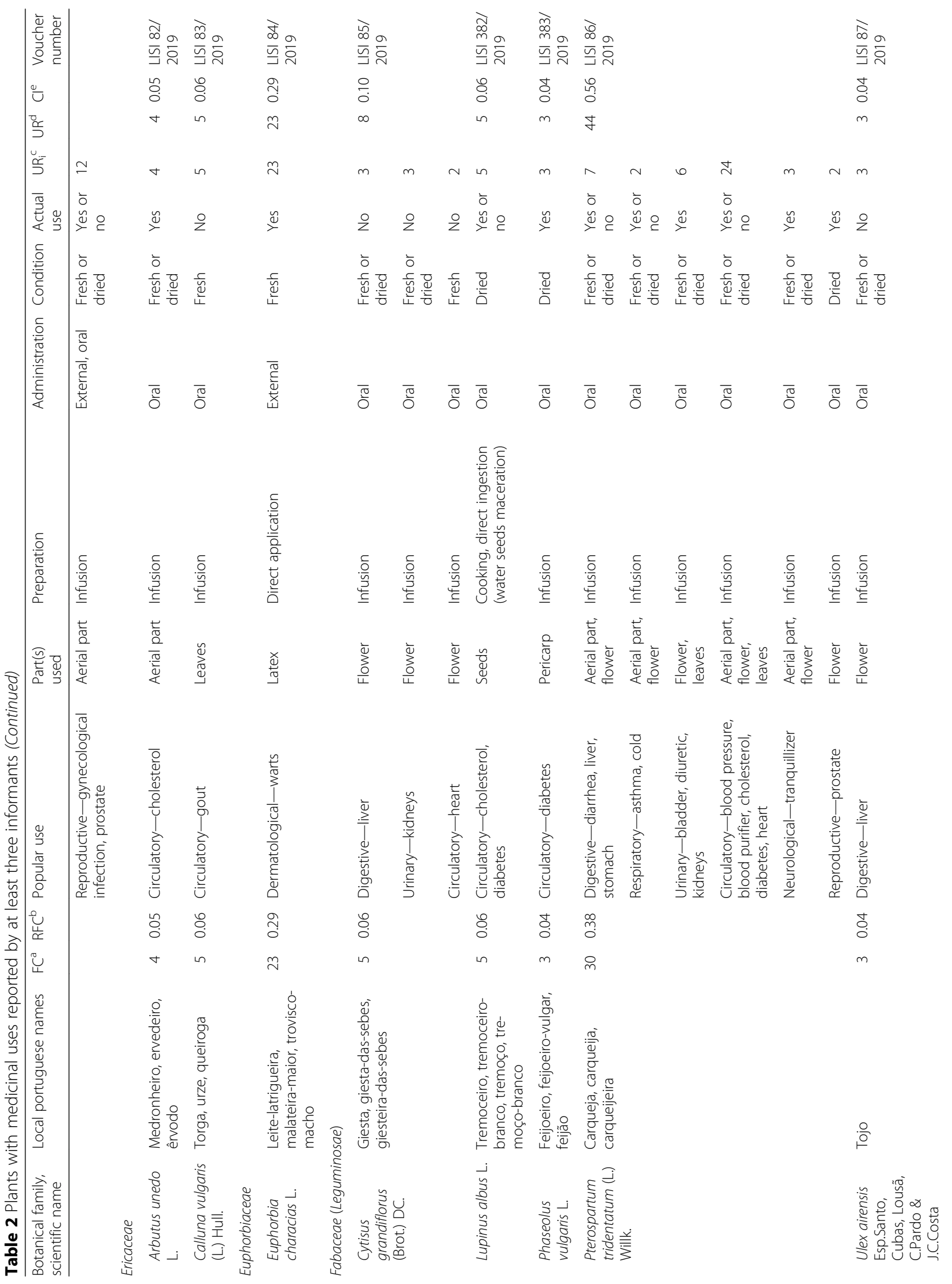




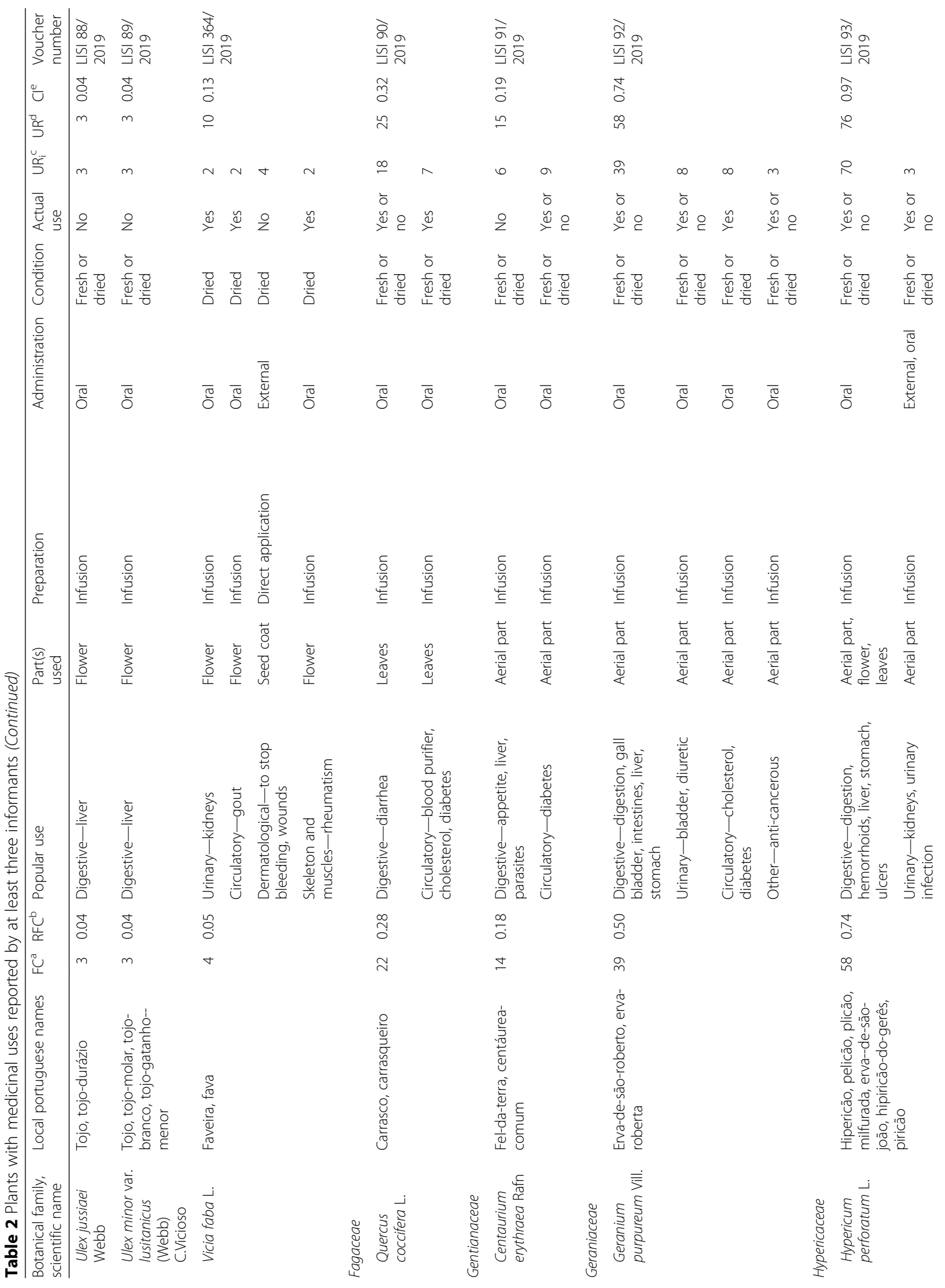




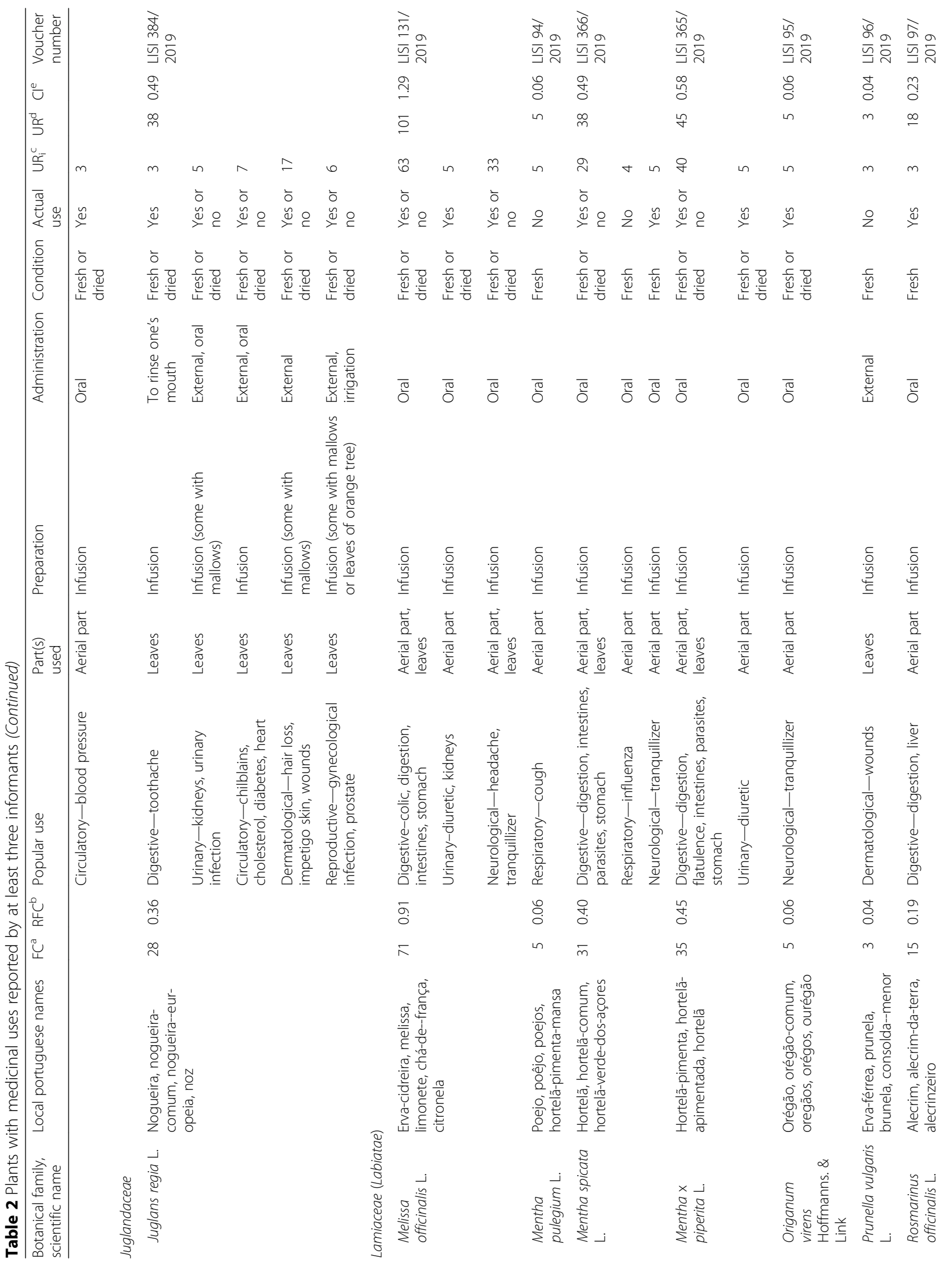




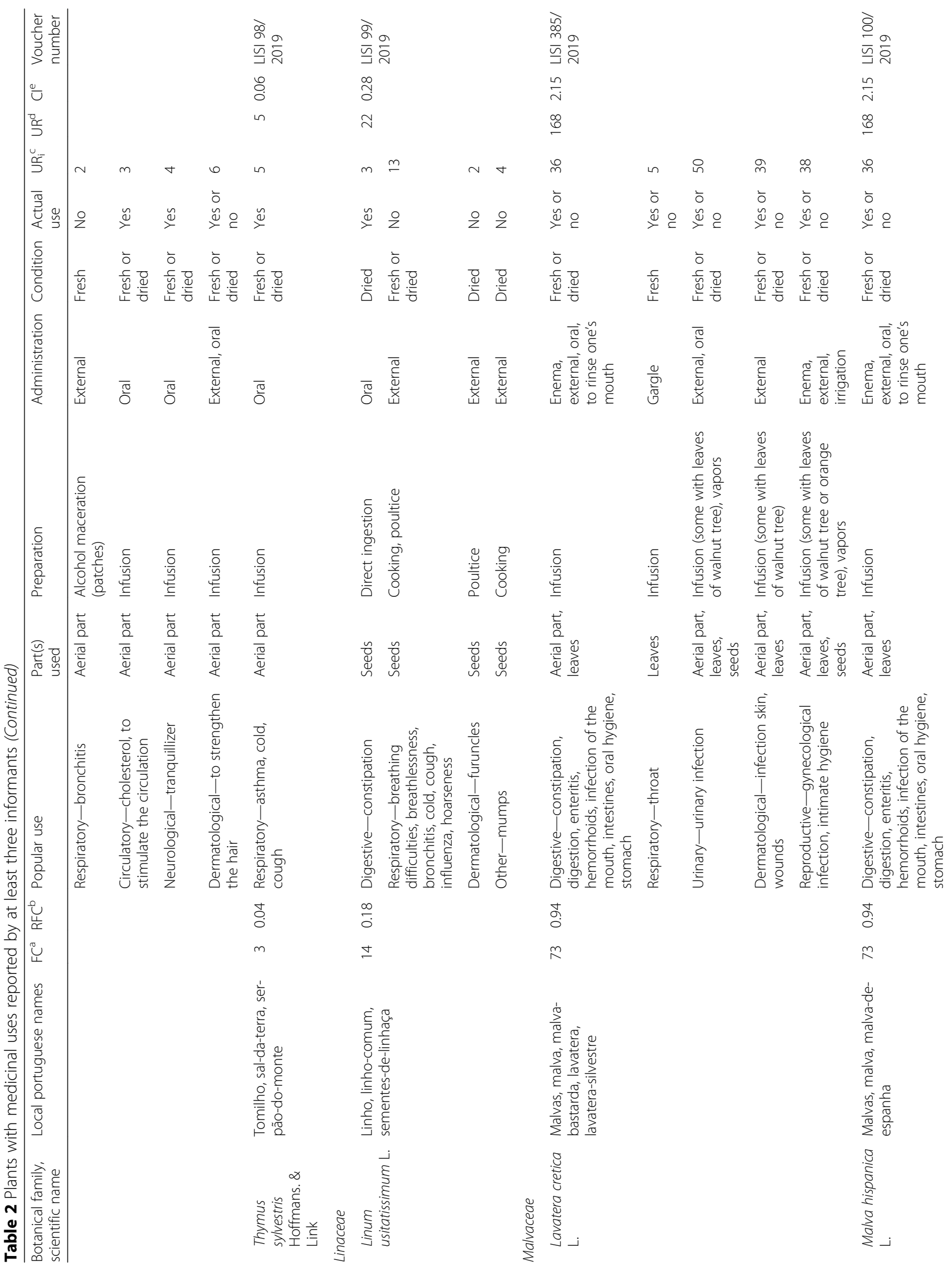




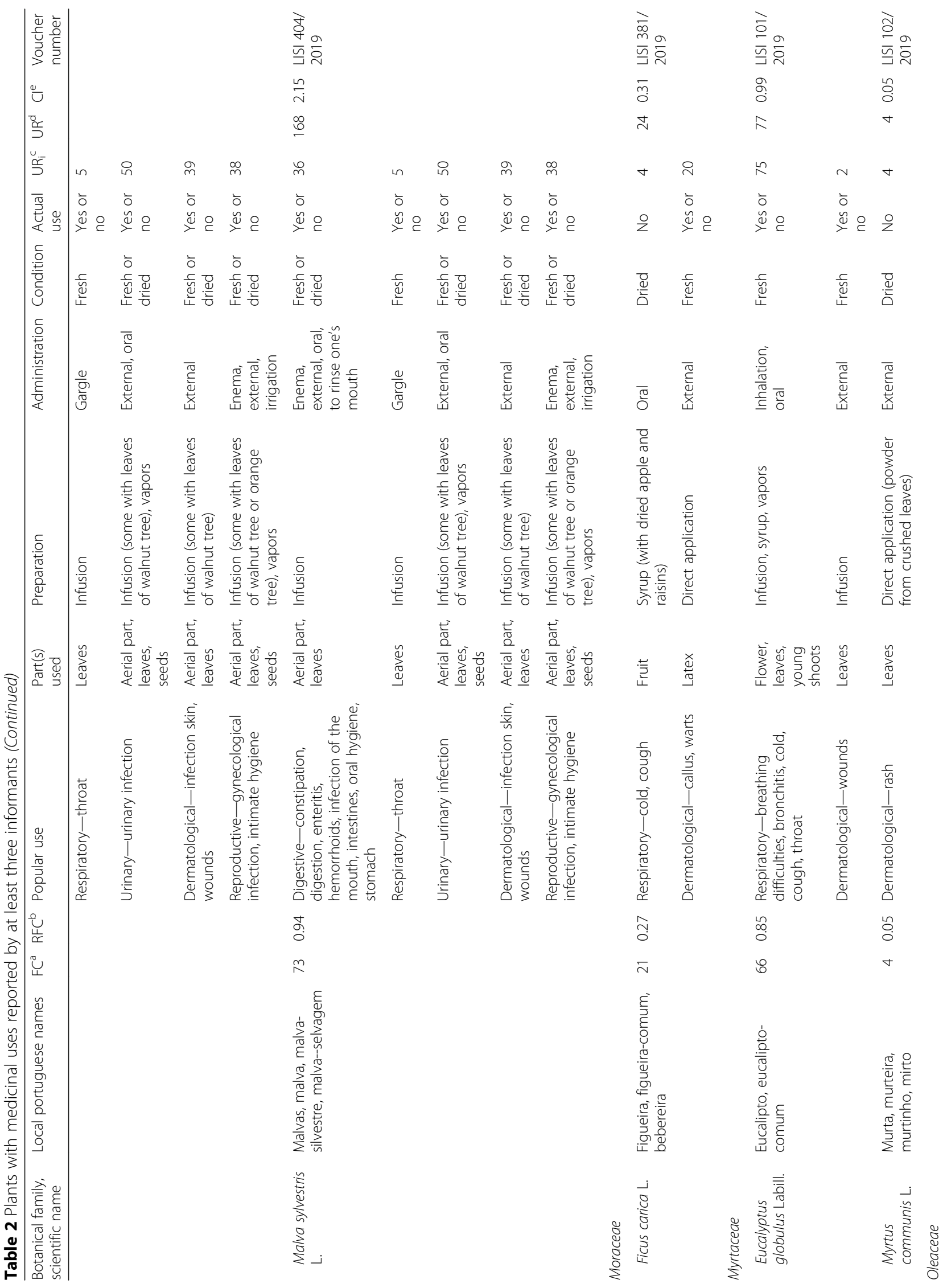




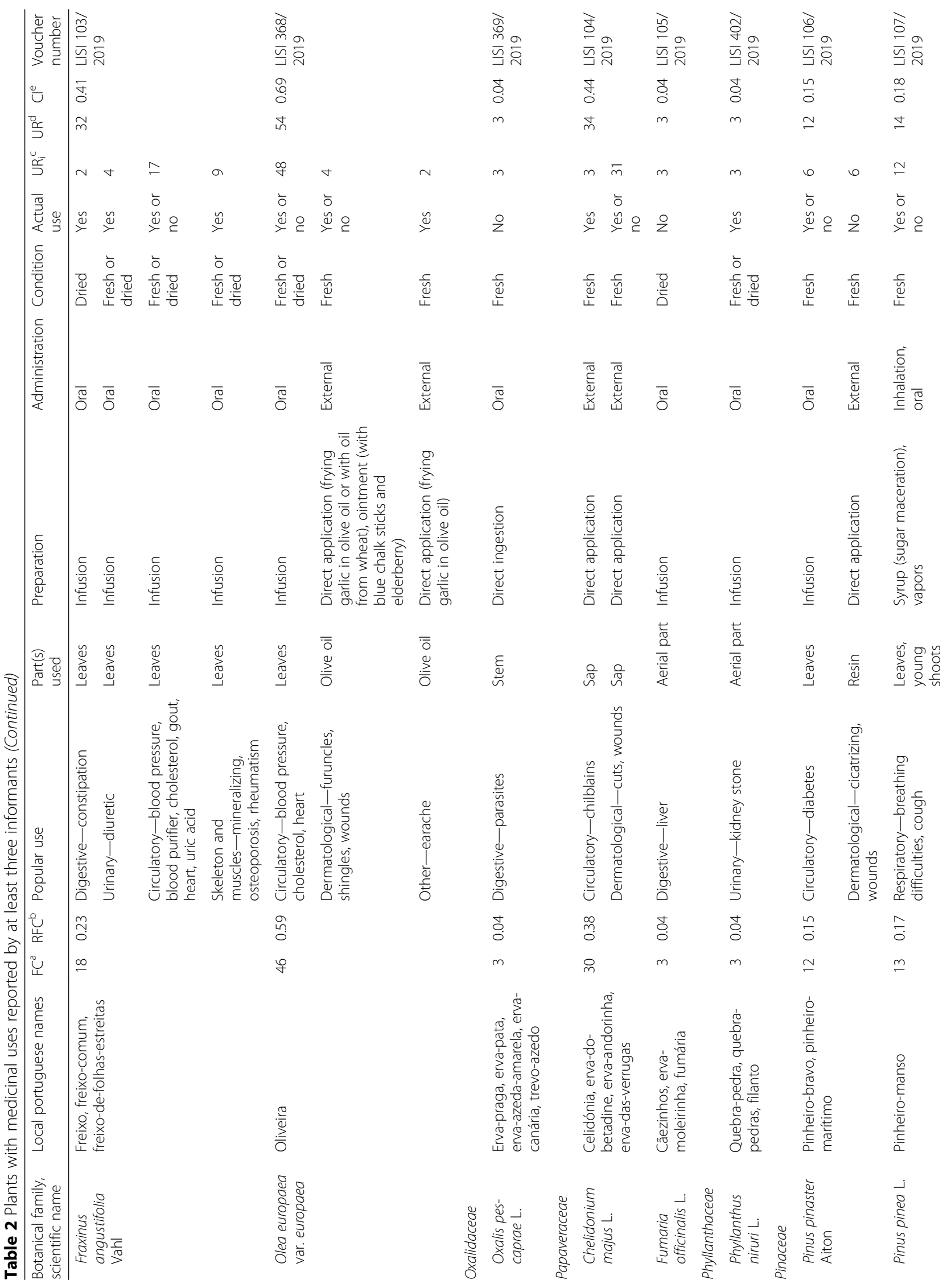




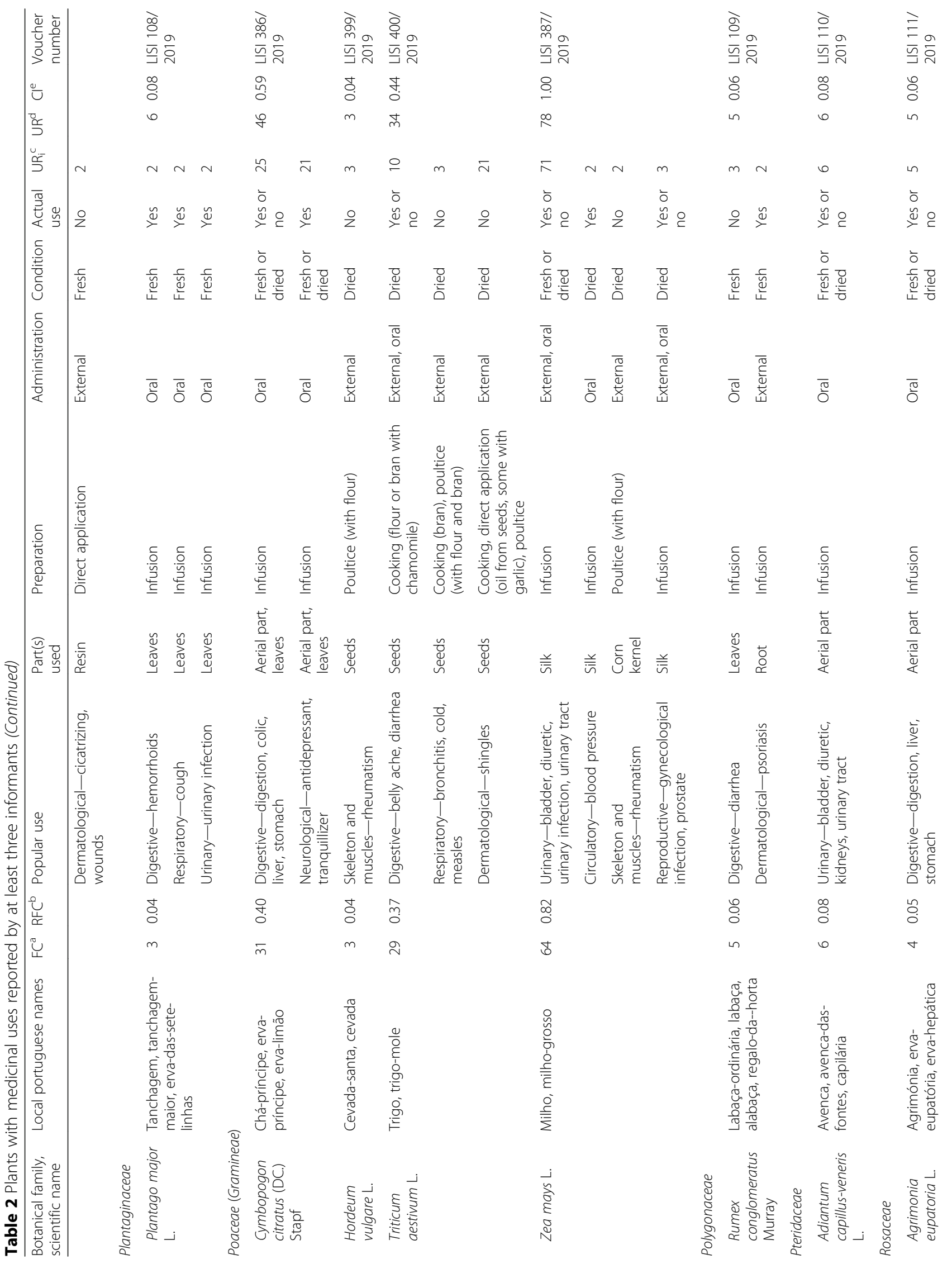




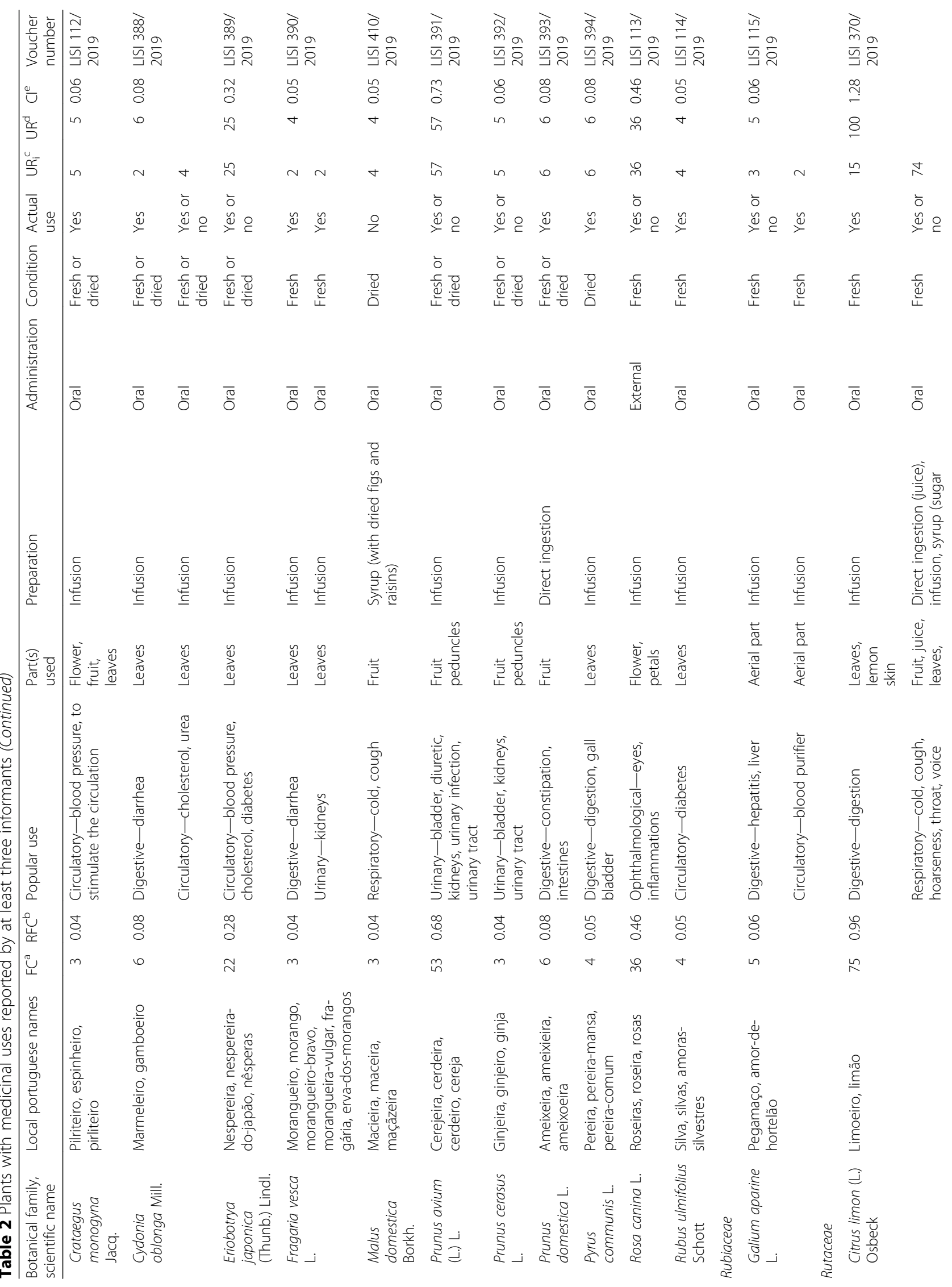




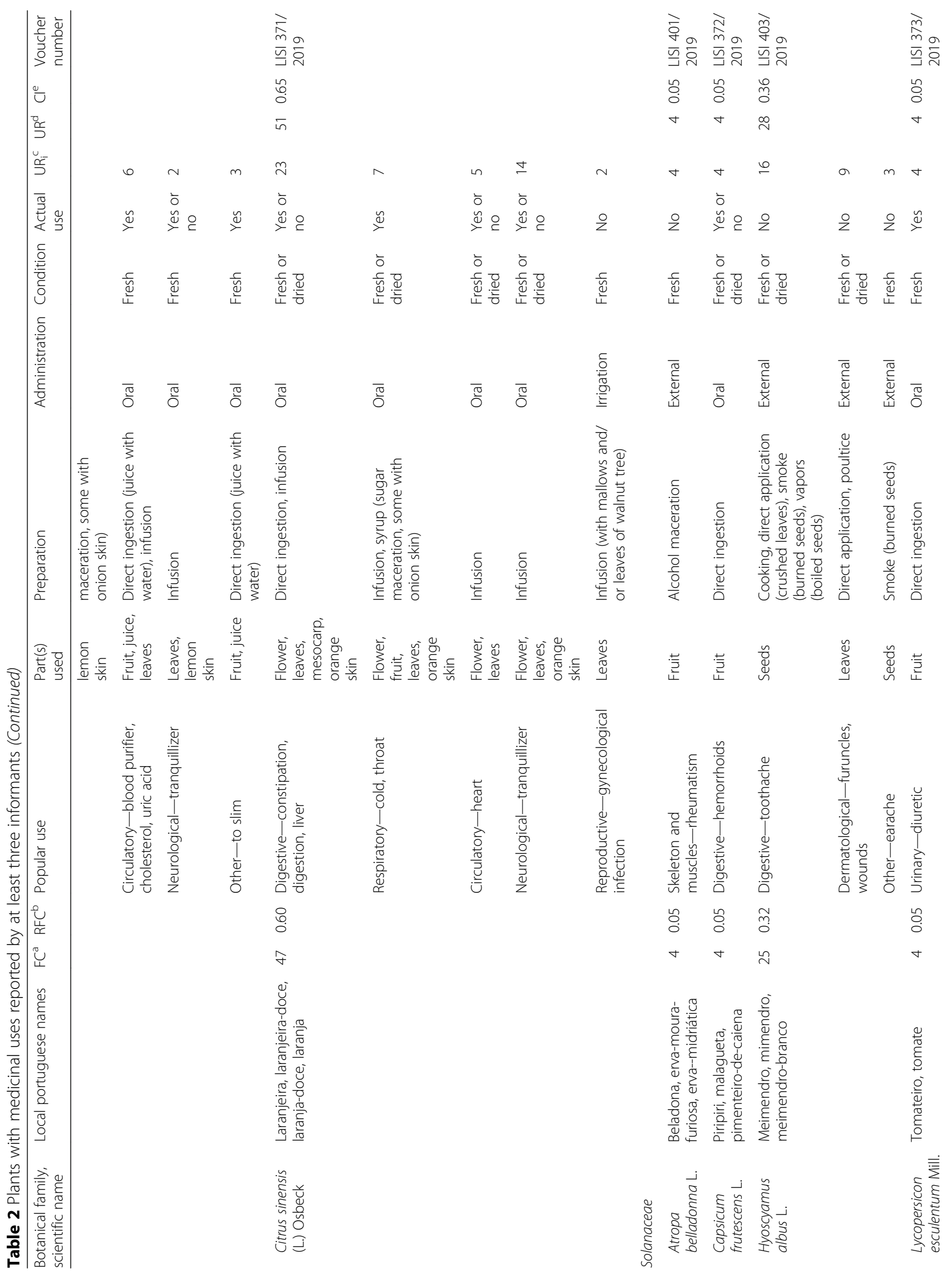




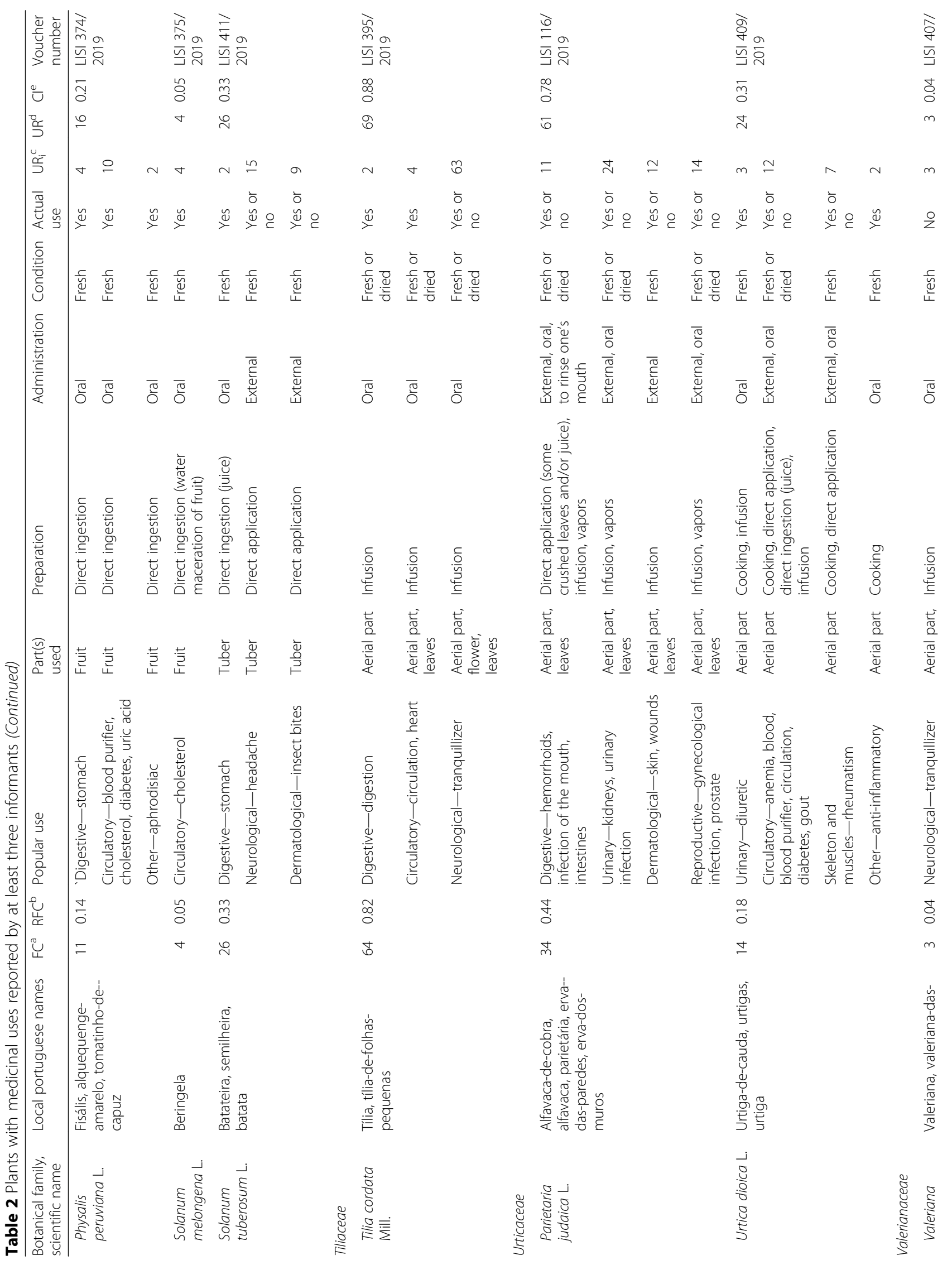




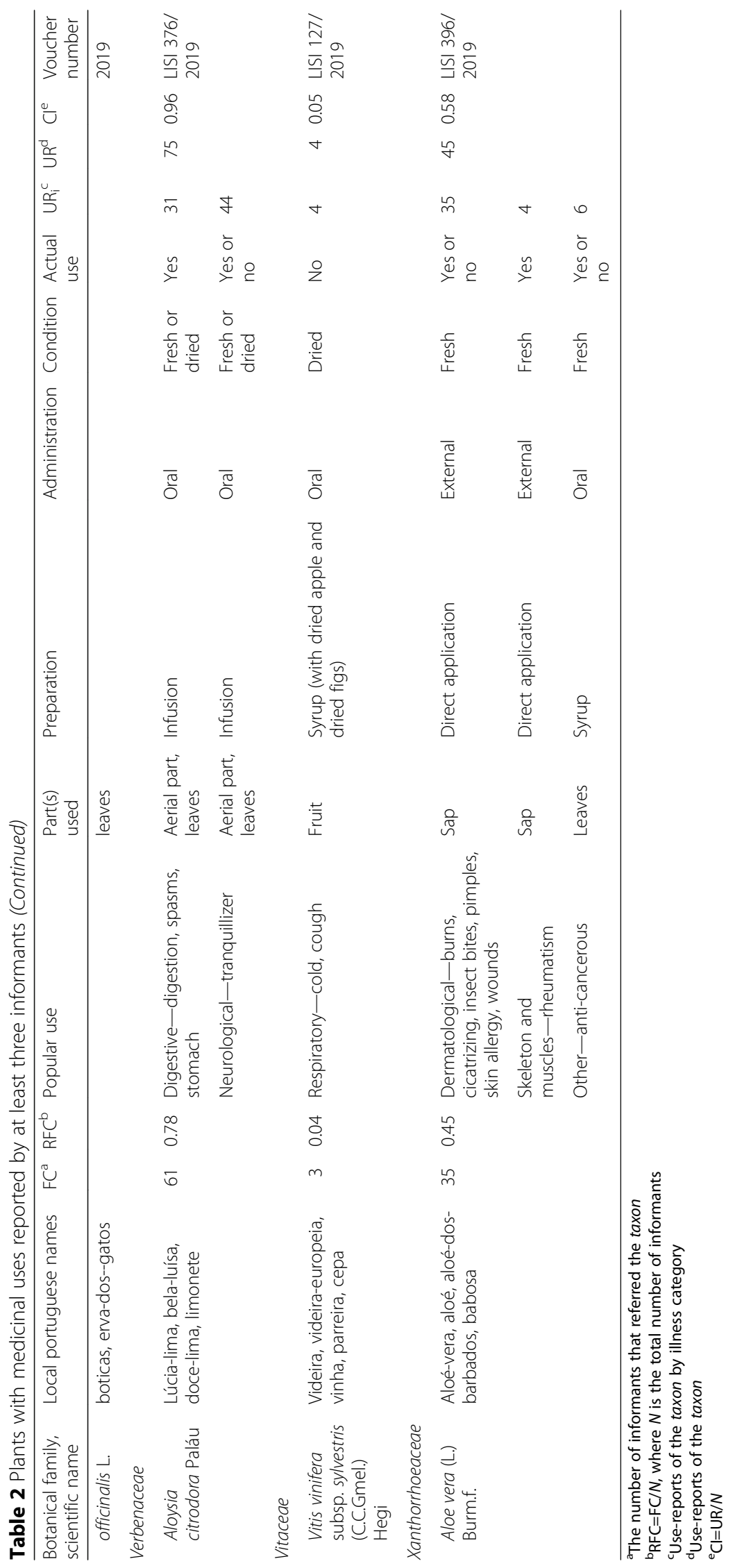



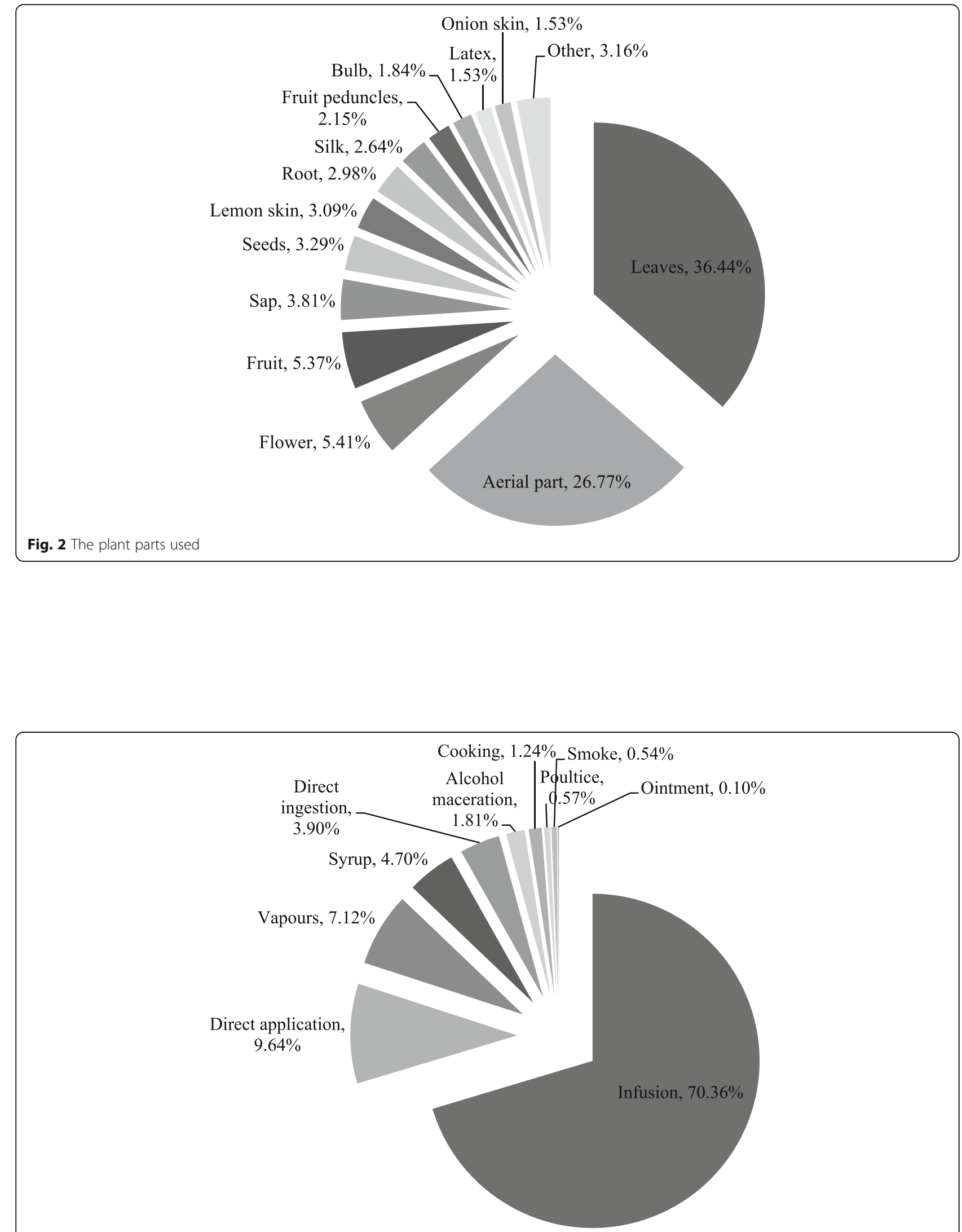

Fig. 3 The preparation of medicinal plants 
preparation of area or used to wash some parts of the body.

It should be noted that poultices were applied fundamentally over a piece of tissue.

Syrup, obtained mainly by sugar maceration, and alcohol maceration, was mostly used for rheumatism (with Allium sativum L., Tamus communis L., and Atropa belladonna L.) or for respiratory purposes like the treatment of bronchitis with patches (with Rosmarinus officinalis L.).

The smoke preparation, with only Hyoscyamus albus L., was applied for earache and toothache.

Almost all of the taxa are used alone as very few mixes have been identified. For example, in the production of poultices, flour was used, and in the preparation of ointments, olive oil and elderberry were used.

The Fig. 4 shows that the two main administration processes were oral (in $61 \%$ of cases, approximately) and external administration (in 33\% of cases, approximately). In other situations were used inhalation, to rinse one's mouth, gargle, irrigation and enema.

To conclude the general analysis of Table 2, it should be noted that only 13 taxa were used in a dried condition as the others were used in fresh and in fresh or dried. A few taxa, 19, were only used in the past, meaning they are no longer used by the populace even though the memory lingers as they were indeed mentioned in the interviews. The average number of plants referred per informant was approximately 26.68. The average number of use-reports referred per informant was equal to 36 . The average number of use-reports referred per taxon is approximately equal to 26.74; the average number of different local Portuguese names per taxon was approximately equal to 2.9. Twenty plants were cited by $50 \%$ or more of interviewees.

\section{Local Portuguese plant names}

Informants used 304 local names to refer to the 105 medicinal taxa cataloged. These names were checked against Portuguese publications that claim to contain all previously published common plant names [3739]. We found several undocumented local names; for example, "bódanha", "erva-da-infeção" and "ervado-betadine". It is also important to note that some local Portuguese names allude to their uses such as "quebra-pedra" (kidney stone of urinary category)Phyllanthus niruri L.- or "erva-hepática" (liver of digestive category)-Agrimonia eupatoria L..

Table 2 has 315 vernacular names because some of them are repeated because different plants can have the same popular name ("pinheirinha", "cavalinha", "rabo-de-cavalo", "tojo", "hortelã", "malva", "malvas" and "limonete").

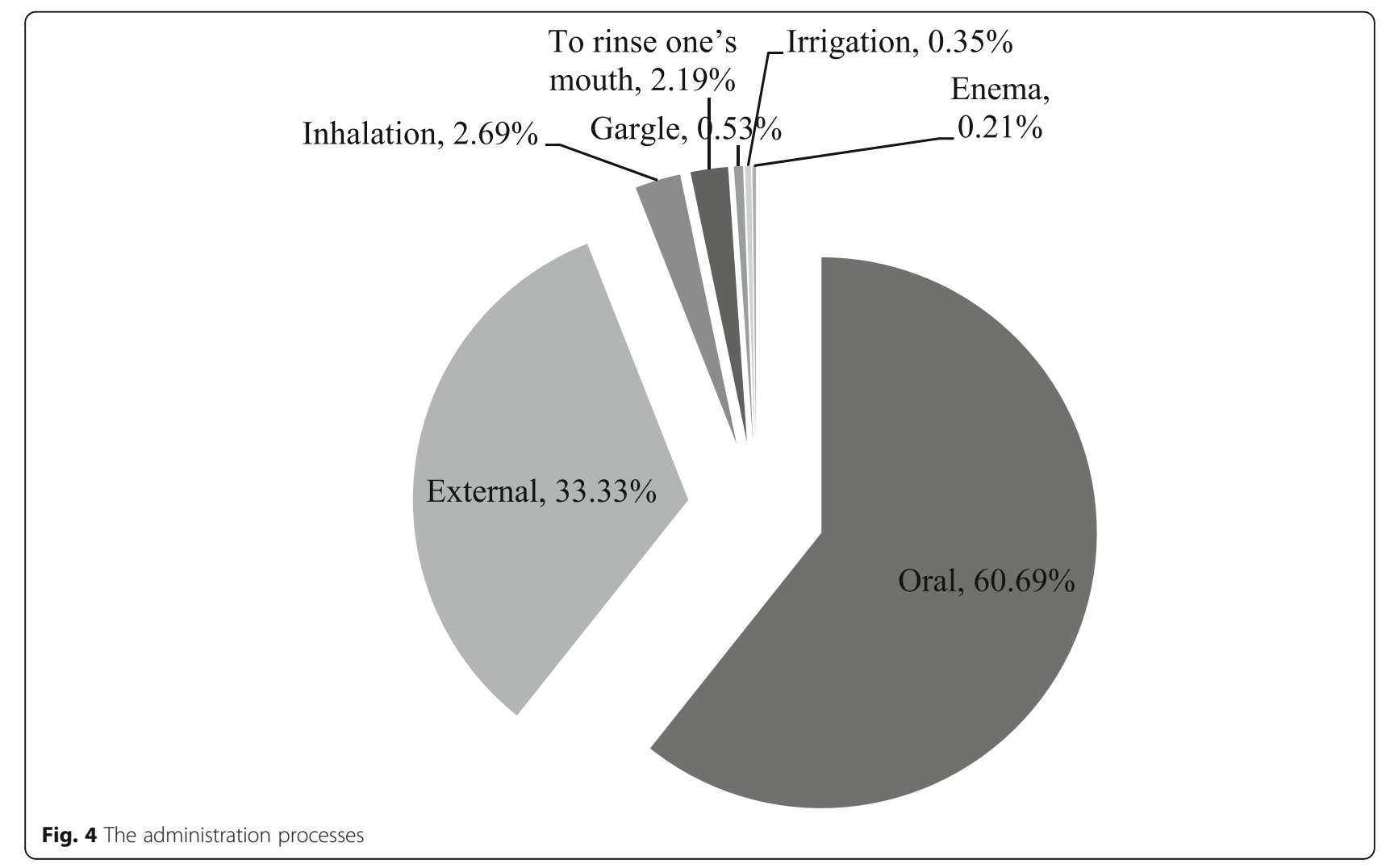




\section{Diseases treated by medicinal plants}

The reported plants were grouped into 10 categories, based on the body systems, each of which is divided into several subcategories, based on the information gathered. Sometimes, the interviewees do not mention specific diseases or conditions; instead, they mention some organs (for example, liver or heart) or some processes (for example, cicatrizing or mineralizing). Figure 5 presents these 10 categories, with 54 taxa being included in the digestive category, 37 in circulatory category, 34 in urinary category, 28 in dermatological category, 27 in respiratory category, 15 in neurological category, 12 in reproductive category, 11 in the skeleton and muscle category, one in ophthalmological category, and 13 in other category (medicinal plants in contexts not covered in the previous categories). It is important to note that most plants are included in more than one category. The number of subcategories varied between two, in the ophthalmological category, and 22 , in the dermatological category, a total of 95 subcategories. Several taxa appear in more than one category.

\section{Digestive category}

Fifty-four medicinal plants were reported for this group. The main species employed to treat digestive problems were $H y$ pericum perforatum L., Melissa officinalis L., and Geranium purpureum Vill., with 70, 63, and 39 use-reports, respectively. In other works carried out in Portugal, these medicinal plants were also mentioned: Hypericum perforatum L. [41-43, 49, 54], Melissa officinalis L. [41-43, 49, 54], and Geranium purpureum Vill. [41, 42, 49].

\section{Circulatory category}

This is a prominent category of plant use, with 37 taxa and 14 subcategories used for purposes related to the circulatory system and blood. The species indicated with the highest number of use-reports were Olea europaea L. var. europaea (48), Eriobotrya japonica (Thunb.) Lindl. (25), and Pterospartum tridentatum (L.) Willk. (24). The first plant was referred in five studies [41-43, 49, 54] and the remaining in two $[49,54]$.

\section{Urinary category}

With 34 taxa, mainly used as an infusion, the most referred were Zea mays L. (71), also referred in other Portuguese studies [41-43, 49, 54]; Prunus avium (L.) L. (57), referred in three $[42,49,54]$; and the species belonging to the Malvaceae family (50 each) that were cited in two previous papers [42, 49]. It is curious to note that this is the only category for which fruit peduncles were used.

\section{Dermatological category}

The interviewees reported 28 plants to treat diseases related to this category. The administration method is fundamentally external. The taxa most cited were those belonging to the Malvaceae family (39 each), Senecio serpens G.D.Rowley (37), and Aloe vera (L.) Burm.f. (35). It has the largest number of subcategories (22) and the interviews reported that wounds can be treated by 19 different plants. Only the species of the Malvaceae family were referenced for similar purposes in Portugal [41, 42, 54].

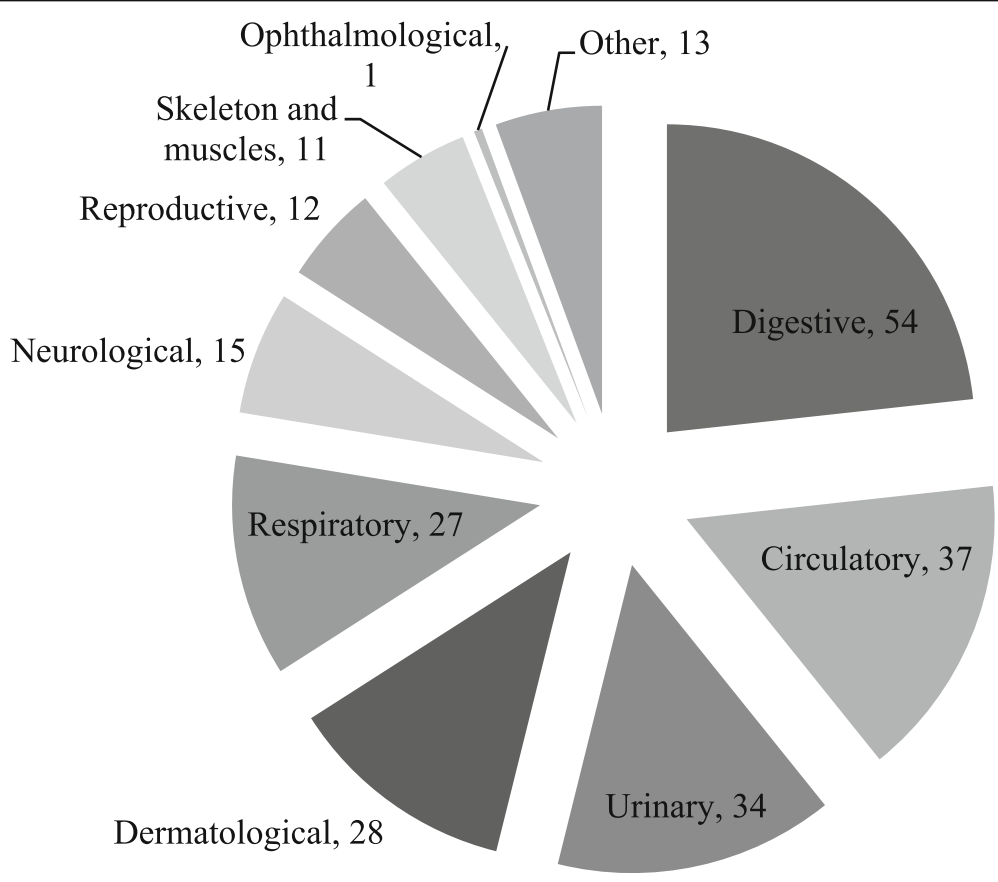

Fig. 5 Number of the taxa for each illness category 


\section{Respiratory category}

Twenty-seven medicinal plants were reported to be used in the treatment of respiratory problems, including $\mathrm{Eu}$ calyptus globulus Labill. (75), Citrus limon (L.) Osbeck (74), and Daucus carota subsp. sativus (Hoffm.) Schübl. \& G. Martens (70). In other works carried out in Portugal, the first species was mentioned in four [41, 42, $49,54]$ and the remainder in three, respectively [41, 42, $49]$ and $[41,42,54]$.

\section{Neurological category}

Fifteen medicinal plants were considered beneficial in this category. The species with the highest number of use-reports were Tilia cordata Mill. (63), Aloysia citrodora Paláu (44), and Melissa officinalis L. (33). The same uses were referred in similar studies carried out in Portugal, namely [41, 42, 49, 54] for Tilia cordata Mill., [42, 49, 54] for Aloysia citrodora Paláu, and [42, 43, 49, 54] for Melissa officinalis L..

\section{Reproductive category}

The informants reported 12 taxa, which belong to nine botanical families (Apiaceae, Cucurbitaceae, Equisetaceae, Fabaceae, Juglandaceae, Malvaceae, Poaceae, Rutaceae, and Urticaceae). The species of Malvaceae family, with 38 use-reports, Parietaria judaica L. (14) and species from Equisetaceae family (12) were the most cited. The first family, Malvaceae, was referred in three studies [41, 42, 49] and the last, Equisetaceae, in two $[49,54]$ such as Parietaria judaica L. [49, 54].

\section{Skeleton and muscles}

Eleven taxa were mentioned. Tamus communis L., Fraxinus angustifolia Vahl, and Allium sativum L. were the species with the highest number of use-reports, 43 , nine and seven, respectively. It is interesting to note that Tamus communis $\mathrm{L}$. is only found in this group. These species were mentioned in works carried out in Portugal for the same uses, namely Tamus communis L. [54], Fraxinus angustifolia Vahl [41, 42, 49, 54], and Allium sativum L. [42, 54].

\section{Ophthalmological category}

It was reported one taxon in this group, Rosa canina L., with 36 use-reports. Note that this taxon is not referred to in any other category and petals were mentioned as the part used only in this instance. Carvalho [54] has also cited this taxon in association with this category.

\section{Other category}

This category has seven subcategories used in contexts unrelated or not connected with the previous categories (anti-cancerous, anti-inflammatory, aphrodisiac, earache, fever, mumps, and to slim). However, 13 of the plants that were reported in this category here were also mentioned in others.

Approximately $22.2 \%$ (10) of the botanical families were reported in relation to only one specific affliction, and approximately $44.8 \%$ (47) of taxa were reported in only one category.

\section{Quantitative assessment of ethnobotanical data}

Characteristics such as homogeneity, importance, and cultural similarity were evaluated using quantitative indices which contributed to make solid comparisons with other independent Portuguese studies using the same methodology contrasting the results with previous works $[41-43,49,54]$ as they relate to the traditional knowledge of medicinal plants used by the Montejunto population.

The ethnobotanical richness $(R)$ is the number of taxa reported in each ethnobotanical study [40]. In this study, $R$ is equal to 105. In similar studies carried out in Portugal, the values obtained were 88 [43], 104 [42], and 150 [41].

As we can see in Table 2, the relative frequency of citation of the reported species ranges from 0.05 to 0.96 . In Fig. 6, we have the 15 botanical taxa with the highest RFC, which reveals the importance of these species. The Citrus limon (L.) Osbeck has the highest value because it was mentioned by 75 informants, followed by Lavatera cretica L., Malva hispanica L., Malva sylvestris L., Daucus carota subsp. sativus (Hoffm.) Schübl. \& G. Martens, and Melissa officinalis L.

In Table 3 and Fig. 7, we present the data relating to the number of use-reports and the correspondent CI, for the botanical taxa with more use-reports. We can see that these 15 medicinal plants mentioned $(14 \%$ of the total) correspond to approximately $50 \%$ of the total usereports in Table 2. According to Table 2, CI ranges from 0.04, for taxa mentioned only by three informants and with only three use-reports (Leucanthemum sylvaticum (Brot.) Nyman, Opuntia maxima Mill., Phaseolus vulgaris L., Ulex airensis Esp.Santo, Cubas, Lousã, C.Pardo \& J.C.Costa, Ulex jussiaei Webb, Ulex minor Roth, Prunella vulgaris L., Oxalis pes-caprae L., Fumaria officinalis L., Phyllanthus niruri L., Hordeum vulgare L. and Valeriana officinalis L.), to 2.15, for Lavatera cretica L., Malva hispanica L., and Malva sylvestris L. The low values of $\mathrm{CI}$, according Tuttolomondo et al. [53], indicate that the local populations had little trust in some of the plants concerning the treatment of certain pathologies or as a strong indication of a gap or fading of traditional plant knowledge regarding their medicinal uses. Note that only three of the plants with CI equal to 0.04 are used nowadays (Leucanthemum sylvaticum (Brot.) Nyman, Phaseolus vulgaris L., and Phyllanthus niruri L.). 


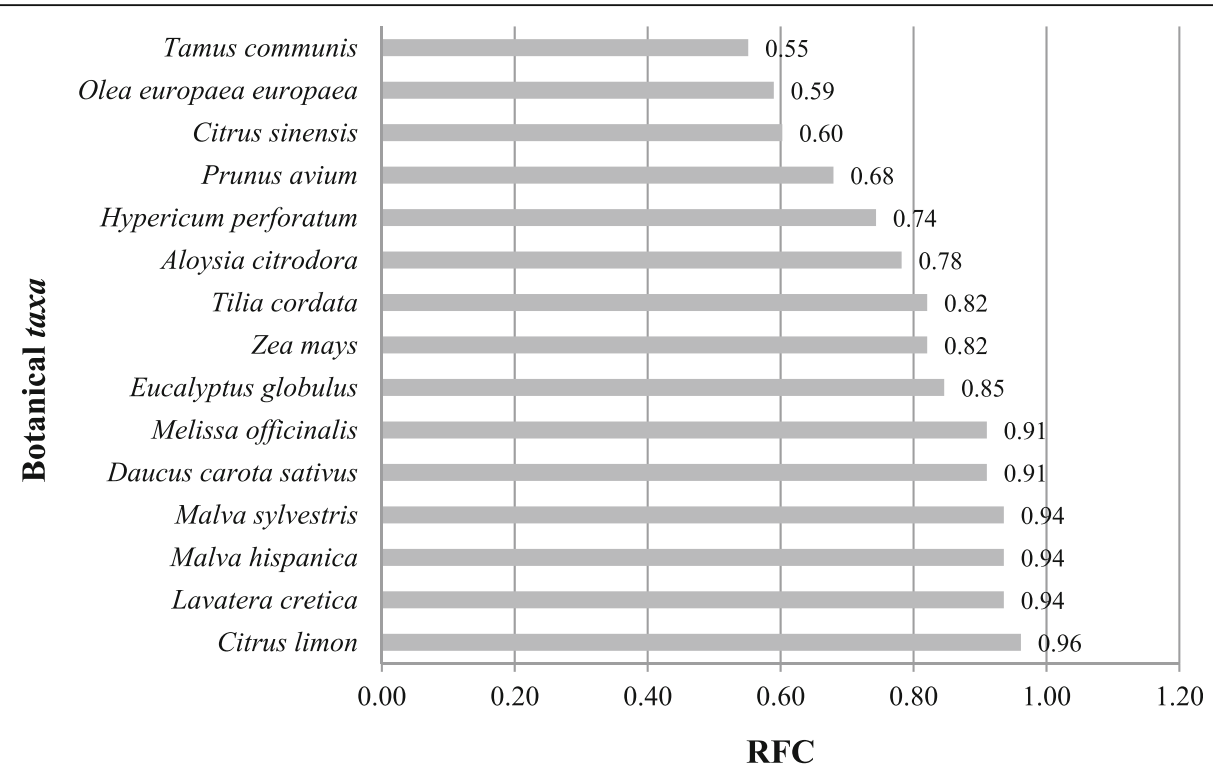

Fig. 6 The botanical taxa with the highest RFC

Table 3 The botanical taxa with more use-reports

\begin{tabular}{|c|c|c|c|c|c|}
\hline Taxa & $U R^{a}$ & $F C^{b}$ & $\begin{array}{l}\text { Number of different } \\
\text { subcategories }\end{array}$ & $\mathrm{Cl}^{\mathrm{C}}$ & Illness categories (in decreasing order) \\
\hline Lavatera cretica L. & 168 & 73 & 14 & 2.15 & $\begin{array}{l}\text { Urinary, dermatological, reproductive, digestive, and } \\
\text { respiratory }\end{array}$ \\
\hline Malva hispanica $\mathrm{L}$. & 168 & 73 & 14 & 2.15 & $\begin{array}{l}\text { Urinary, dermatological, reproductive, digestive, and } \\
\text { respiratory }\end{array}$ \\
\hline Malva sylvestris $L$. & 168 & 73 & 14 & 2.15 & $\begin{array}{l}\text { Urinary, dermatological, reproductive, digestive, and } \\
\text { respiratory }\end{array}$ \\
\hline Melissa officinalis L. & 101 & 71 & 8 & 1.29 & Digestive, neurological, and urinary \\
\hline Citrus limon (L.) Osbeck & 100 & 75 & 11 & 1.28 & $\begin{array}{l}\text { Respiratory, digestive, circulatory, other, and } \\
\text { neurological }\end{array}$ \\
\hline Zea mays L. & 78 & 64 & 8 & 1.00 & $\begin{array}{l}\text { Urinary, reproductive, circulatory, skeleton, and } \\
\text { muscles }\end{array}$ \\
\hline Eucalyptus globulus Labill. & 77 & 66 & 6 & 0.99 & Respiratory and dermatological \\
\hline Hypericum perforatum L. & 76 & 58 & 8 & 0.97 & Digestive, urinary, and circulatory \\
\hline Aloysia citrodora Paláu & 75 & 61 & 4 & 0.96 & Neurological and digestive \\
\hline $\begin{array}{l}\text { Daucus carota subsp. sativus (Hoffm.) Schübl. \& } \\
\text { G.Martens }\end{array}$ & 72 & 71 & 3 & 0.92 & Respiratory and digestive \\
\hline Tilia cordata Mill. & 69 & 64 & 4 & 0.88 & Neurological, circulatory, and digestive \\
\hline Equisetum arvense L. & 64 & 40 & 15 & 0.82 & $\begin{array}{l}\text { Urinary, reproductive, circulatory, digestive, skeleton, } \\
\text { and muscles }\end{array}$ \\
\hline Equisetum telmateia Ehrh. & 64 & 40 & 15 & 0.82 & $\begin{array}{l}\text { Urinary, reproductive, circulatory, digestive, skeleton, } \\
\text { and muscles }\end{array}$ \\
\hline Parietaria judaica L. & 61 & 34 & 9 & 0.78 & Urinary, reproductive, dermatological, and digestive \\
\hline Geranium purpureum Vill. & 58 & 39 & 10 & 0.74 & Digestive, urinary, circulatory, and other \\
\hline
\end{tabular}

${ }^{\mathrm{a}}$ The number of use-reports

${ }^{b}$ The number of informants that referred the taxon

${ }^{\mathrm{C}} \mathrm{Cl}=\mathrm{UR} / \mathrm{N}$ 


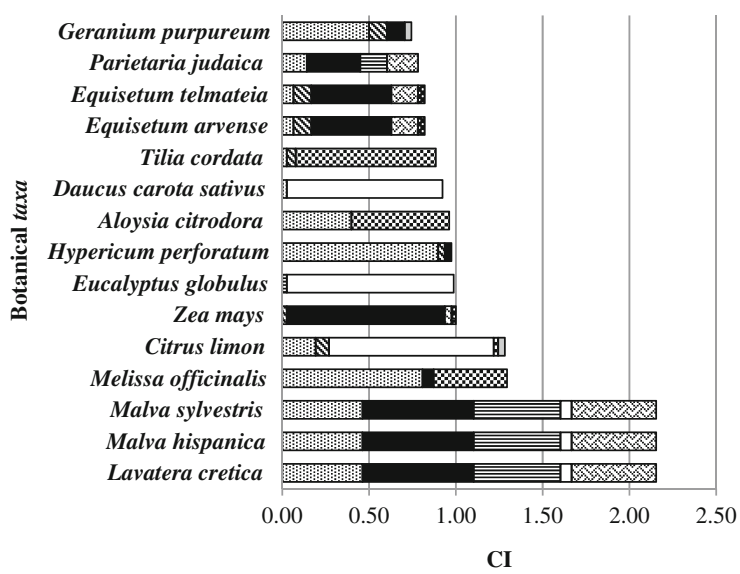

国 Digestive

\$Circulatory

-Urinary

目Dermatological

$\square$ Respiratory

Neurogical

Reproductive

Skeleton and muscles

Ophthalmological

$\square$ Other

Fig. 7 The botanical taxa with the highest $\mathrm{Cl}$

The average $F_{\mathrm{IC}}$ value for all categories is 0.90 , higher than the value obtained in other Portuguese studies [41, 43], which are respectively 0.85 and 0.48 . The high $F_{\text {IC }}$ values found in most of the medicinal categories reflect a high level of homogeneity in consensus among the users and indicate that natural remedies are still considered extremely effective

In Table 4, we have presented some important data for each category, namely the number of taxa, the incidence, the number of use-reports, the $F_{\mathrm{IC}}$, and the medicinal importance. Through the analysis of this table, we find that $F_{\mathrm{IC}}$ varies from 0.69 for the category "other" to 1.00 for the ophthalmological category. Note that the value of 1.00 for the ophthalmological category is due to the fact that all informants indicated the same purpose for the taxon they mentioned.

\section{Comparison with similar studies from the Mediterranean region}

In the following, taking into account the quantitative data collected, during the interviews, we present solid comparisons with other similar studies using the same methodology. In this context, Table 5 shows some quantitative data on medicinal plants in 11 regions, including this study. The data collected from various regions of Portugal, Spain, and other Mediterranean countries [41, $43,48,51-53,55-58]$ are presented by the year of publication.

The table shows that in terms of ethnobotanical richness, $R$, there are three studies with lower values than this study. However, this corresponds to the second best value for Portugal. The value obtained for $F_{\mathrm{IC}}, 0.90$, is similar to the higher values recorded for the other

Table 4 Informant consensus factor $\left(F_{\mathrm{IC}}\right)$ and medicinal importance (MI) of medicinal plants

\begin{tabular}{|c|c|c|c|c|c|}
\hline Illness category & $\begin{array}{l}\text { Number of taxa } \\
\left(n_{t}\right)^{\mathrm{a}}\end{array}$ & $\begin{array}{l}\text { Incidence } \\
(\%)^{\mathrm{b}}\end{array}$ & $\begin{array}{l}\text { Number of use-reports } \\
\left(n_{\mathrm{ur}}\right)\end{array}$ & $\begin{array}{l}\text { Informant consensus factor } \\
\left(F_{1 C}\right)^{c}\end{array}$ & $\begin{array}{l}\text { Medicinal importance } \\
(\mathrm{MI})^{d}\end{array}$ \\
\hline Digestive & 54 & 51.43 & 659 & 0.92 & 12.20 \\
\hline Circulatory & 37 & 35.24 & 278 & 0.87 & 7.51 \\
\hline Urinary & 34 & 32.38 & 483 & 0.93 & 14.21 \\
\hline Dermatological & 28 & 26.67 & 427 & 0.94 & 15.25 \\
\hline Respiratory & 27 & 25.71 & 375 & 0.93 & 13.89 \\
\hline Neurological & 15 & 14.29 & 254 & 0.94 & 16.93 \\
\hline Reproductive & 12 & 11.43 & 169 & 0.93 & 14.08 \\
\hline $\begin{array}{l}\text { Skeleton and } \\
\text { muscles }\end{array}$ & 11 & 10.48 & 87 & 0.88 & 7.91 \\
\hline Ophthalmological & 1 & 0.95 & 36 & 1.00 & 36.00 \\
\hline Other & 13 & 12.38 & 40 & 0.69 & 3.08 \\
\hline
\end{tabular}

${ }^{a}$ A taxon may be listed in several of the categories of medicinal usage

${ }^{\mathrm{b}}$ As percentage of records on the total of 105 records

${ }^{c} F_{\mathrm{IC}}=\left(n_{\mathrm{ur}}-n_{\mathrm{t}}\right) /\left(n_{\mathrm{ur}}-1\right)$

${ }^{\mathrm{d}} \mathrm{MI}=n_{\mathrm{ur}} / n_{t}$ 
Table 5 Quantitative ethnobotanical data in several Mediterranean territories

\begin{tabular}{|c|c|c|c|c|c|}
\hline Regions & $R^{a}$ & $F^{b}$ & $N^{c}$ & $R / N$ & $F_{1 C}{ }^{d}$ \\
\hline Montseny, Spain —2003 [55] & 351 & 89 & 172 & 2.04 & 0.91 \\
\hline Serra de São Mamede, Portugal_-2003 [41] & 150 & - & 45 & 3.33 & 0.85 \\
\hline Western Pyrenees, Spain—2007 [56] & 92 & - & 88 & 1.05 & 0.65 \\
\hline Trás-os-Montes, Portugal—2009 [43] & 88 & 42 & 46 & 1.91 & 0.48 \\
\hline Alt Empordà, Spain —2009 [57] & 335 & 80 & 178 & 1.88 & 0.91 \\
\hline Middle Navarra, Spain—2011 [51] & 198 & 60 & 276 & 0.72 & 0.86 \\
\hline Eastern Mallorca, Balearic Islands_2012 [52] & 121 & 64 & 42 & 2.88 & 0.71 \\
\hline Nebrodi Regional Park Sicily, Italy_2014 [53] & 90 & 44 & 226 & 0.40 & $0.54-0.94$ \\
\hline Bozyazı, Turkey—2015 [58] & 159 & 55 & 178 & 0.89 & $0.11-0.74$ \\
\hline Mount Hermon, Lebanon—2015 [48] & 124 & 42 & 53 & 2.34 & $0.66-0.94$ \\
\hline Serra de Montejunto, Portugal & 105 & 46 & 78 & 1.35 & 0.90 \\
\hline
\end{tabular}

${ }^{\mathrm{a}}$ The ethnobotanical richness

${ }^{\mathrm{b}}$ The number of families

'The number of informants

${ }^{\mathrm{d}} F_{\mathrm{IC}}=\left(n_{\mathrm{ur}}-n_{t}\right) /\left(n_{\mathrm{ur}}-1\right)$

studies, which indicates a high degree of consensus among the informants.

\section{Medicinal plants reported by one or two informants}

The previous statistical study was based on the plants reported by three or more independent informants. However, it is also considered important to present the list of plants that were reported by only one or two informants (Table 6), because, although they may be less statistically significant, they may reflect the acculturation that has occurred in the last half-century in the industrialized western countries, such as those of Western Europe, where, at least partially, a modern culture is being adopted in detriment of the traditional one [59].

\section{Conclusion}

This work was a crystallization of the experience and a way to take another look at the ethnopharmacological knowledge unearthed and explored throughout the experience. The fieldwork also allowed the inventory of 105 taxa with medicinal properties used by the population from the Protected Landscape of "Serra de Montejunto" (Lisbon District, Portugal), where studies on the traditional uses of plants were nonexistent. The plants were distributed among 10 categories and 95 subcategories according to their uses where digestive category included the largest number of plant species.

The botanical families Rosaceae, Asteraceae, Fabaceae, and Lamiaceae were those with the greatest species representation, which can be explained by the predominance of these families in the Mediterranean flora and also because they include some common plants. Although the properties of these families are used in pharmacology, they were not necessarily the most cited.
The leaves and aerial part were most often used in the preparation of medicinal concoctions, followed by the flower and fruit. The infusion and direct application preparations were the most frequently used and oral administration largely predominated over another one. The plant was also most often used fresh.

Most plants referred in this study are still in use today. Only 17 are no longer used at the present time because habits have changed. For example, due to the availability of medicinal products in pharmacies, Atropa belladonna L., Ecballium elaterium (L.) A. Rich., Gomphrena globosa L., Hyoscyamus albus L., and Valeriana officinalis L. are no longer favored.

The informants reported 315 common names for the medicinal plants, 11 of which are repeated because different plants have the same local name.

In quantitative terms, by analyzing some ethnobotanical data, we obtained similar results to other studies carried out in the Mediterranean region.

Two of the most cited plants, Senecio serpens G.D.Rowley and Aloe vera (L.) Burm.f., are not referenced in other studies, yet they are used by the locals. A more detailed analysis should be done relating to these two plants correlating with its use and the predominance of their mention by the interviewees.

As shown by our analysis of data collected, both through field research and interviews, the use of medicinal plants based on folk knowledge is still very much common in the region studied and still transmitted through the generations. Some of the younger generations living in rural areas turn to the plant knowledge of their ancestors instead of looking for a pharmacy. However, it is still possible for it to disappear from memory which is why these studies, where the memory is preserved and transmitted in writing, properly cataloged 


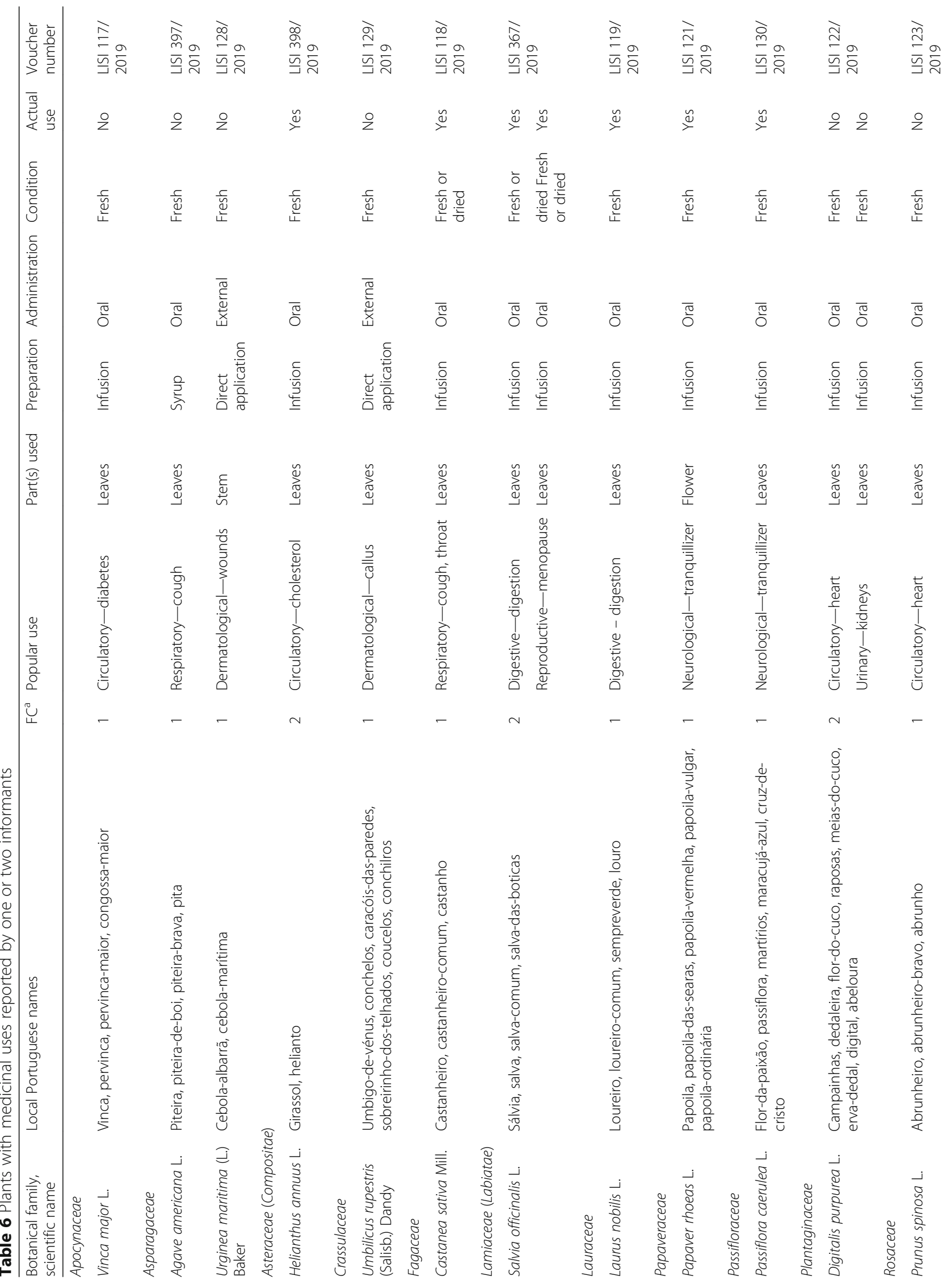




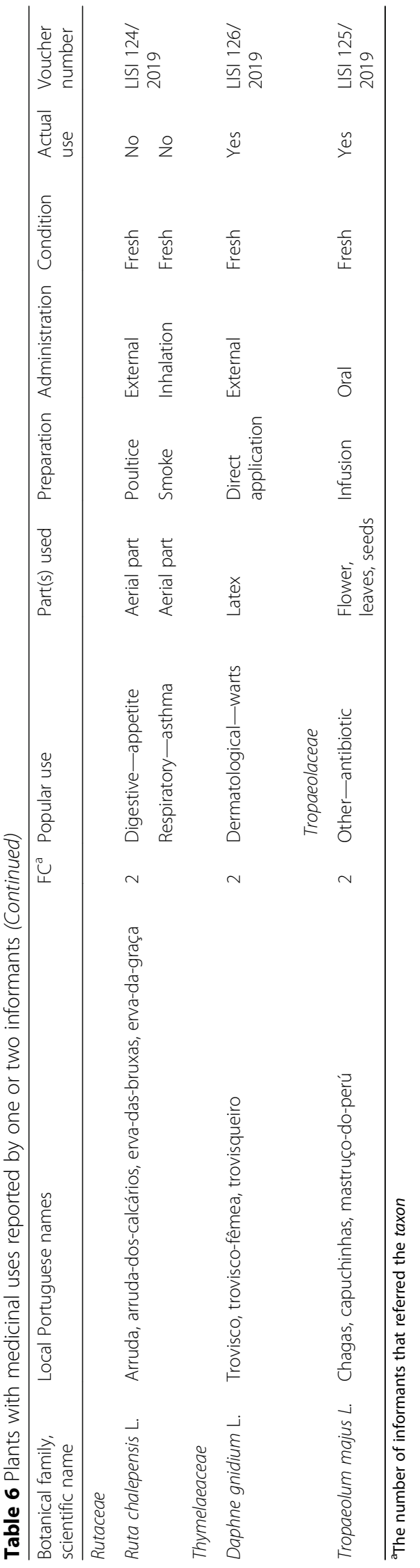


and analyzed, are vital. They also may encourage others, younger and/or outsiders, to take an interest in the plants and their uses as well as in investigating the traditions and the possibilities. However, a detailed analysis of each category and the benefits associated with the plants mentioned is still needed.

\section{Acknowledgements}

We owe our gratitude to the people who shared their knowledge. We formed deep bonds with them, and without their contributions and practical knowledge, it would have been hard, if not impossible, to gather the information that became the basis of this work. Our hope is to help in the preservation effort of the uses of medicinal plants, past and present, as they relate to our cultural heritage, both national and regional.

\section{Authors' contributions}

The authors carried out the entire study: they designed the study, conducted the fieldwork, identified the plant species, did data analysis, and wrote the manuscript. All authors read, corrected, and approved the final manuscript.

\section{Funding}

This work has been partially supported by the national funds by FCT Fundação para a Ciência e a Tecnologia within the project UID/MAT/04674/ 2013 (Sandra Vinagre is a member of the Research Center for Mathematics and Applications, University of Évora).

\section{Availability of data and materials}

The authors already included all data in the manuscript collected during the field surveys.

\section{Ethics approval and consent to participate}

Before conducting interviews, oral consent was received from informants regarding data collection and publication. No further ethics approval was required. Ethical guidelines of the International Society of Ethnobiology (http://www.ethnobiology.net/) were strictly followed.

\section{Consent for publication}

This manuscript does not contain any individual person's data, and further consent for publication is not required.

\section{Competing interests}

The authors declare that they have no competing interests.

\section{Author details}

'Agrupamento de Escolas Severim de Faria - Évora, Estrada das Alcáçovas, 7005-205 Évora, Portugal. '2Departamento de Matemática, CIMA, ECT, Universidade de Évora, Rua Romão Ramalho, 59, 7000-671 Évora, Portugal.

\section{Received: 10 October 2018 Accepted: 12 June 2019}

Published online: 01 July 2019

\section{References}

1. Camejo-Rodrigues JS. Estudo etnobotânico das plantas aromáticas e medicinais. In: Figueiredo AC, Barroso JG, Pedro LG, editors. Potencialidades e Aplicações das Plantas Aromáticas e Medicinais, Curso Teórico-Prático. Lisboa: Edição da Faculdade de Ciências da Universidade de Lisboa Centro de Biotecnologia Vegetal; 2007. p. 168-74.

2. Harshberger JW. The purposes of ethno-botany. Bot Gaz. 1896:21(3):146-54.

3. Balick M, Cox P. Plants, people and culture. The science of ethnobotany. New York: Scientific American Library; 1996.

4. Albuquerque UP. Introdução à etnobotânica. 2nd ed. Rio de Janeiro: Editora Interciência; 2005

5. Oliveira Feijão R. Medicina pelas Plantas, Colecção Vida e Saúde. 6th ed Lisboa: Gráfica Imperial, Lda; 1973

6. Proença da Cunha A, Roque OR, Gaspar N. Cultura e Utilização das Plantas Medicinais e Aromáticas. 2nd ed. Lisboa: Fundação Calouste Gulbenkian; 2013.

7. Agelet A, Vallès J. Studies on pharmaceutical ethnobotany in the region of Pallars (Pyrenees, Catalonia, Iberian Peninsula). Part I. general results and new or very rare medicinal plants. J Ethnopharmacol. 2001;77:57-70.
8. Decreto Regulamentar no. 11/99, 22 July 1999. Diário da República no. 169, Série I-B.

9. Costa JC, Aguiar C, Capelo JH, Lousã M, Neto C. Biogeografia de Portugal Continental. Quercetea. 1998:0:5-56.

10. Rivas-Martínez S. Mapas de series, geoseries y geopermaseries de vegetación de España, Memoria del mapa de vegetación potencial de España. Parte I Itin Geobot. 2007;17:5-436.

11. Rivas-Martínez S, Rivas-Sáenz S, Penas A. Worldwide bioclimatic classification system. Global Geobot. 2011;1:1-634+4 Maps.

12. Monteiro-Henriques T. Fitossociologia e paisagem da bacia hidrográfica do rio Paiva. Lisboa: PhD thesis, Universidade Técnica de Lisboa; 2010.

13. Vinagre C. Flora e Vegetação da Paisagem Protegida da Serra de Montejunto. Évora: PhD thesis, Universidade de Évora; 2017.

14. Alexiades MN. Collecting ethnobotanical data: an introduction to basic concepts and techniques. In: Alexiades MN, editor. Selected guidelines for ethnobotanical research: a field manual. New York: The New York Botanical Garden; 1996. p. 53-94.

15. Coutinho A. A Flora de Portugal (Plantas Vasculares). 2nd ed. Lisboa: Livraria Bertrand; 1939.

16. Franco JA. Nova Flora de Portugal (Continente e Açores). Vol. I. Lisboa: Edição do Autor; 1971.

17. Franco JA. Nova Flora de Portugal (Continente e Açores). Vol. II. Lisboa: Edição do Autor; 1984

18. Franco JA, Rocha-Afonso ML. Nova Flora de Portugal (Continente e Açores). Vol. III. Fasc. I. Lisboa: Escolar Editora; 1994.

19. Franco JA, Rocha-Afonso ML. Nova Flora de Portugal (Continente e Açores), vol. III. Fasc. II. Lisboa: Escolar Editora; 1998.

20. Franco JA, Rocha-Afonso ML. Nova Flora de Portugal (Continente e Açores), vol. III. Fasc. III. Lisboa: Escolar Editora; 2003.

21. Castroviejo S, Laínz M, López González G, Montserrat P, Muñoz Garmendia F. Paiva J, Villar L. Flora iberica. Plantas vasculares de la Península Ibérica e Islas Baleares: Lycopodiaceae-Papaveraceae. Vol. I. 1st ed. Madrid: Real Jardín Botánico, CSIC; 1986

22. Castroviejo S, Laínz M, López González G, Montserrat P, Muñoz Garmendia F, Paiva J, Villar L. Flora iberica. Plantas vasculares de la Península Ibérica e Islas Baleares: Platanaceae-Plumbaginaceae (partim). Vol. II. 1st ed. Madrid: Real Jardín Botánico, CSIC; 1990.

23. Castroviejo S, Aedo C, Gómez Campo C, Laínz M, Montserrat P, Morales R, Muñoz Garmendia F, Nieto Feliner G, Rico E, Talavera S, Villar L. Flora iberica. Plantas vasculares de la Península Ibérica e Islas Baleares: CruciferaeMonotropaceae. Vol. IV. 1st ed. Madrid: Real Jardín Botánico, CSIC; 1993.

24. Castroviejo S, Aedo C, Benedí C, Laínz M, Muñoz Garmendia F, Nieto Feliner G, Paiva J. Flora iberica. Plantas vasculares de la Península Ibérica e Islas Baleares: Haloragaceae-Euphorbiaceae. Vol. VIII. 1st ed. Madrid: Real Jardín Botánico, CSIC; 1997.

25. Castroviejo S, Muñoz Garmendia F, Navarro C. Flora iberica. Plantas vasculares de la Península Ibérica e Islas Baleares: Rosaceae. Vol. VI. 1st ed. Madrid: Real Jardín Botánico, CSIC; 1998

26. Castroviejo S, Talavera S, Aedo C, Romero Zarco C, Sáez L, Salqueiro FJ, Velayos M. Flora iberica. Plantas vasculares de la Península Ibérica e Islas Baleares: Leguminosae (partim). Vol. VII (I). 1st ed. Madrid: Real Jardín Botánico, CSIC; 1999

27. Castroviejo S, Talavera S, Aedo C, Herrero A, Romero Zarco C, Salgueiro FJ, Velayos M. Flora iberica. Plantas vasculares de la Península Ibérica e Islas Baleares: Leguminosae (Partim). Vol. VII (II). 1st ed. Madrid: Real Jardín Botánico, CSIC; 2000

28. Castroviejo S, Nieto Feliner G, Jury SL, Herrero A. Flora iberica. Plantas vasculares de la Península Ibérica e Islas Baleares: Araliaceae-Umbelliferae. Vol. X. 1st ed. Madrid: Real Jardín Botánico, CSIC; 2003.

29. Castroviejo S, Aedo C, Cirujano S, Laínz M, Montserrat P, Morales R, Muñoz Garmendia F, Navarro C, Paiva J, Soriano C. Flora iberica. Plantas vasculares de la Península Ibérica e Islas Baleares: Plumbaginaceae (partim)Capparaceae. Vol. III. 2nd ed. Madrid: Real Jardín Botánico, CSIC; 2005.

30. Castroviejo S, Devesa JA, Gonzalo R, Herrero A. Flora iberica. Plantas vasculares de la Península Ibérica e Islas Baleares: Rubiaceae-Dipsacaceae. Vol. XV. 1st ed. Madrid: Real Jardín Botánico, CSIC; 2007.

31. Castroviejo S, Benedí C, Rico E, Güemes J, Herrero A. Flora iberica. Plantas vasculares de la Península Ibérica e Islas Baleares: PlantaginaceaeScrophulariaceae. Vol. XIII. 1st ed. Madrid: Real Jardín Botánico, CSIC; 2009.

32. Castroviejo S, Morales R, Quintanar A, Cabezas F, Pujadas AJ, Cirujano S. Flora iberica. Plantas vasculares de la Península Ibérica e Islas Baleares: 
Verbenaceae-Labiatae-Callitrichaceae. Vol. XII. 1st ed. Madrid: Real Jardín Botánico, CSIC; 2010.

33. Castroviejo S, Talavera S, Andrés C, Arista M, Fernández Piedra MP, Gallego MJ, Ortiz PL, Romero Zarco C, Salgueiro FJ, Silvestre S, Quintanar A. Flora iberica. Plantas vasculares de la Península Ibérica e Islas Baleares: GentianaceaeBoraginaceae. Vol. XI. 1st ed. Madrid: Real Jardín Botánico, CSIC; 2012.

34. Castroviejo S, Rico E, Crespo MB, Quintanar A, Herrero A, Aedo C. Flora iberica. Plantas vasculares de la Península Ibérica e Islas Baleares: LiliaceaeAgavaceae. Vol. XX. 1st ed. Madrid: Real Jardín Botánico, CSIC; 2013.

35. Castroviejo S, Devesa JA, Quintanar A, García MÁ. Flora iberica. Plantas vasculares de la Península Ibérica e Islas Baleares: Compositae (partim). Vol. XVI (I). 1st ed. Madrid: Real Jardín Botánico, CSIC; 2014.

36. Castroviejo S, Muñoz Garmendia F, Navarro C, Quintanar A, Buira A. Flora iberica. Plantas vasculares de la Península Ibérica e Islas Baleares: RhamnaceaePolygalaceae. Vol. IX. 1st ed. Madrid: Real Jardín Botánico, CSIC; 2015.

37. Rocha F. Nomes Vulgares de Plantas Existentes em Portugal. Lisboa: Ministério da Agricultura, do Desenvolvimento Rural e das Pescas; 1996.

38. Fernandes F, Carvalho L. Portugal Botânico de A a Z - Plantas Portuguesas e Exóticas. Lisboa: Lidel - Edições Técnicas, Lda.; 2003.

39. Arias B. Nombres vulgares de las plantas en la Península lbérica e Islas Baleares. Madrid: PhD thesis, Universidad Autónoma de Madrid; 2006.

40. Begossi A. Use of ecological methods in ethnobotany: diversity indices. Econ Bot. 1996:50:280-9.

41. Camejo-Rodrigues JS, Ascensão L, Bonet MÁ, Vallès J. An ethnobotanical study of medicinal and aromatic plants in the Natural Park of "Serra de São Mamede" (Portugal). J Ethnopharmacol. 2003;89:199-209.

42. Carvalho L. Estudos de Etnobotânica e Botânica Económica no Alentejo. Coimbra: PhD thesis, Universidade de Coimbra; 2006.

43. Neves JM, Matos C, Moutinho C, Queiroz G, Gomes LR. Ethnopharmacological notes about ancient uses of medicinal plants in Trásos-Montes (northern of Portugal). J Ethnopharmacol. 2009;124:270-83.

44. Tardío J, Pardo-de-Santayana M. Cultural importance indices: a comparative analysis based on the useful wild plants of southern Cantabria (northern Spain). Econ Bot. 2008:62(1):24-39.

45. Pardo-de-Santayana M, Tardío J, Blanco E, Carvalho AM, Lastra JJ, San Miguel E, Morales R. Traditional knowledge of wild edible plants used in the northwest of the Iberian Peninsula (Spain and Portugal): a comparative study. J Ethnobiol Ethnomed. 2007;3:27.

46. Trotter RT, Logan MH. Informant consensus: a new approach for identifying potentially effective medicinal plants. In: Etkin NL, editor. Plants in indigenous medicine and diet: behaviour approaches. New York: Redgrave publishing company, Bredfort Hills; 1986. p. 91-112.

47. Bonet MA, Parada M, Selga A, Vallés J. Studies on pharmaceutical ethnobotany in the regions of L'Alt Empordá and Les Guilleries (Catalonia, Iberian Peninsula). J Ethnopharmacol. 1999;68:145-68.

48. Baydoun $\mathrm{S}$, Lamis $\mathrm{C}$, Helena D, Nelly A. Ethnopharmacological survey of medicinal plants used in traditional medicine by the communities of Mount Hermon, Lebanon. J Ethnopharmacol. 2015;173:139-56.

49. Novais MH, Santos I, Mendes S, Pinto-Gomes C. Studies on pharmaceutical ethnobotany in Arrábida Natural Park (Portugal). J Ethnopharmacol. 2004;93: 183-95.

50. González-Tejero MR, Casares-Porcel M, Sánchez-Rojas CP, Ramiro-Gutiérrez JM, Molero-Mesa J, Pieroni A, Giusti E, Censorii E, Pasquale C, Della A, Paraskeva-Hadijchambi D, Hadjichambis A, Houmani Z, El-Demerdash M, ElZayat M, Hmamouchi M, ElJohrig S. Medicinal plants in the Mediterranean area: synthesis of the results of the project Rubia. J Ethnopharmacol. 2008; 116:341-57.

51. Cavero RY, Akerreta S, Calvo MI. Pharmaceutical ethnobotany in the Middle Navarra (Iberian Peninsula). J Ethnopharmacol. 2011:137:844-55.

52. Carrió E, Vallès J. Ethnobotany of medicinal plants used in Eastern Mallorca (Balearic Islands, Mediterranean Sea). J Ethnopharmacol. 2012;141:1021-40

53. Tuttolomondo T, Licata M, Leto C, Bonsangue G, Gargano ML, Venturella G, La Bella S. Popular uses of wild plant species for medicinal purposes in the Nebrodi Regional Park (north-eastern Sicily, Italy). J Ethnopharmacol. 2014; 157:21-37.

54. Carvalho AM. Etnobotánica del Parque Natural de Montesinho. Plantas, tradición y saber popular en un territorio del Nordeste de Portugal. Madrid: PhD thesis, Universidad Autónoma; 2005.

55. Bonet MA, Vallès J. Pharmaceutical ethnobotany in the Montseny bosphere reserve (Catalonia, Iberian Peninsula). General results and new or rarely reported medicinal plants. J Pharm Pharmacol. 2003:55:259-70.
56. Akerreta S, Cavero RY, Calvo MI. First comprehensive contribution to medical ethnobotany of Western Pyrenees. J Ethnobiol Ethnomed. 2007;3:26.

57. Parada $M$, Carrió E, Bonet MA, Vallès J. Ethnobotany of the Alt Empordà region (Catalonia, Iberian Peninsula) Plants used in human traditional medicine. J Ethnopharmacol. 2009;124:609-18.

58. Sargin SA. Ethnobotanical survey of medicinal plants in Bozyazı district of Mersin, Turkey. J Ethnopharmacol. 2015;173:105-26.

59. Ember CR, Ember M. Antropología cultural. 8th ed. Madrid: Prentice Hall; 1997.

\section{Publisher's Note}

Springer Nature remains neutral with regard to jurisdictional claims in published maps and institutional affiliations.
Ready to submit your research? Choose BMC and benefit from:

- fast, convenient online submission

- thorough peer review by experienced researchers in your field

- rapid publication on acceptance

- support for research data, including large and complex data types

- gold Open Access which fosters wider collaboration and increased citations

- maximum visibility for your research: over $100 \mathrm{M}$ website views per year

At BMC, research is always in progress.

Learn more biomedcentral.com/submissions 